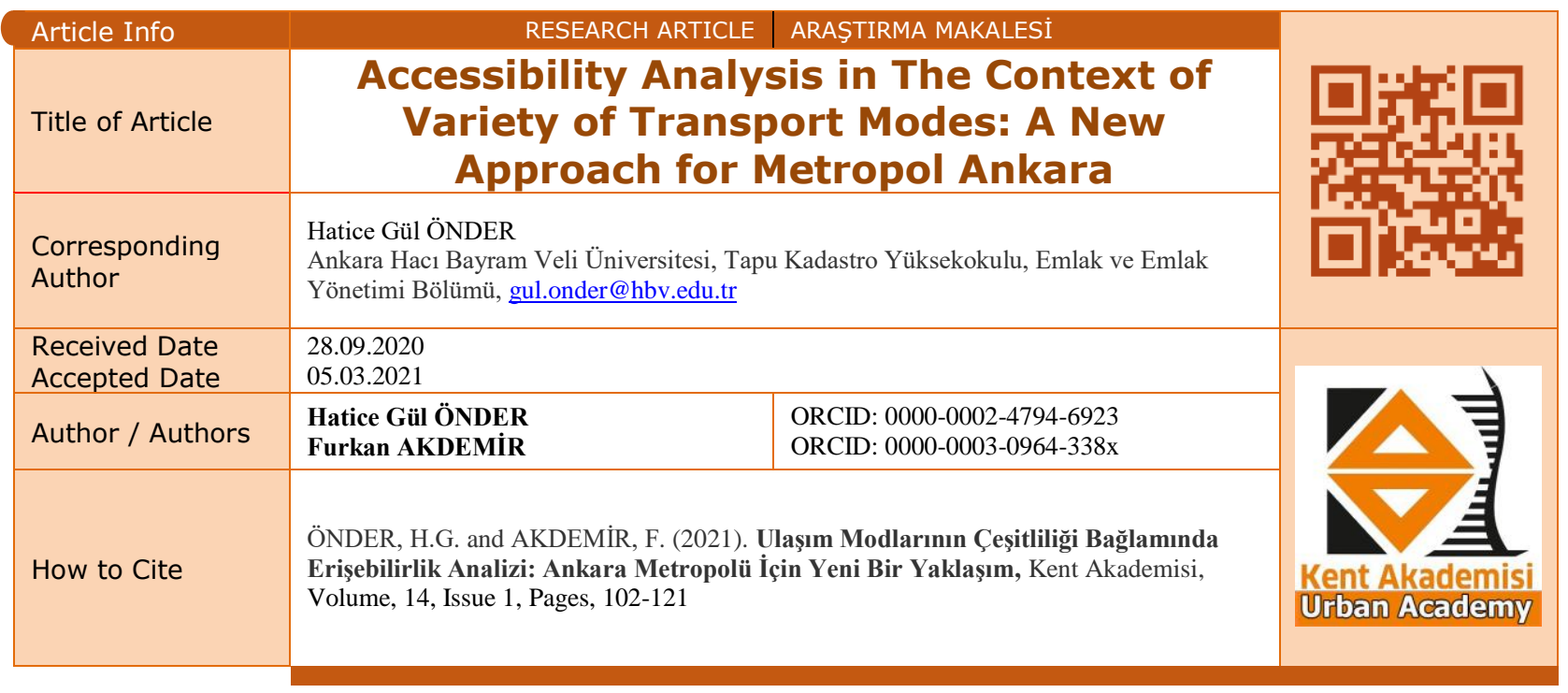

\title{
Ulaşım Modlarının Çeşitliliği Bağlamında Erişebilirlik Analizi: Ankara Metropolü İçin Yeni Bir Yaklaşım
}

\begin{abstract}
:
In line with their needs and possibilities, people are putting various forms of spatial use to the environment in which they live, In the long run, the increasing of type use patterns of the environment and the environment itself is growing. The dimension of transportation that creates the connection in spatial interaction is accessibility. Accessibility refers to the qualitative and quantitative aspect of the transportation connection as a concept. In this study, different from the literature, a new accessibility calculation model is developed by using the quantity and quality values of urban transportation vehicles such as service, distance, number of vehicles, vehicle type in Ankara city metropolitan area sample. In addition, a new type of representation has been developed to easily understand the structure of transportation - accessibility between spaces, to show the accessibility level of social groups in spaces, and to determine the level of accessibility on the basis of social groups that can be used as a guiding tool in planning and investment decision-makings. According to the results of the study, the accessibility level of districts such as Çankaya, Yenimahlle and Altındağ, which have the most transportation diversity, is 5 times higher than the districts which are Kahramankazan, Çubuk and Gölbaşı. In the evaluation made on the basis of social groups, it is seen that the transportation infrastructure of Ankara city can respond better to the needs of low income groups compared to other social groups
\end{abstract}

KEYWORDS: Ankara, Accesibility, Transportation

\footnotetext{
${ }^{1}$ Ankara Hacı Bayram Veli University, Academy of Land Registry and Cadastre, Department of Real Estate and Property Management, gul.onder@hbv.edu.tr

${ }^{2}$ Ankara Metropolitan Municipality, Transport Planning and Rail System Department, Directorate of Planning and Implementation, $\underline{\text { akdemirfurkan10@gmail.com }}$
} 


\section{ÖZ:}

İnsanlar, yaşam sürdüğü çevreye, ihtiyaç ve imkânlar doğrultusunda çeşitli mekânsal kullanım biçimleri yüklemektedir. Zamanla kullanım biçimlerinin artması çevreyi dönüştürmekte ve çevre giderek büyümektedir. Büyüyen çevrenin kullanıcıları olan insanlar, mekânlar arası etkileşimde ulaşım aracılığı ile bağ kurmaktadır. Ulaşımın, mekânsal etkileşimde bağ yapısını oluşturan boyutu ise erişebilirliktir. Erişebilirlik, kavram olarak ulaşım bağının niteliksel ve niceliksel yönünü işaret etmektedir. Literatürde erişebilirliğin teorik düzeyine ilişkin yapılan daha önceki hesaplamalarda yaygın olarak arazi kullanım türleri, uzaklık, fayda, dışsallıklar gibi ölçütlerden yararlanılmaktadır. Bu çalışmada Ankara kenti metropoliten alan örnekleminde literatürden farklı olarak kent içi ulaşım taşıtlarının hizmet, mesafe, taşıt sayısı, taşı türü gibi nicelik ve nitelik değerleri kullanılarak yeni bir erişebilirlik düzeyi hesaplama modeli geliştirilmektedir. Ayrıca mekânlar arası ulaşım - erişebilirlik yapısının kolay anlaşılması için yeni bir gösterim türü, mekânlardaki sosyal grupların erişebilirlik düzeyinin ortaya çıkarılması ve planlama, yatırım kararı alma faaliyetlerinde bir yönlendirici araç olarak kullanılabilecek sosyal grup bazında erişebilirlik düzeyi belirleme modeli geliştirilmiştir. Çalışmanın sonucuna göre en fazla ulaşım çeşitliliğine sahip Çankaya, Yenimahalle, Altındağ gibi ilçelerin erişebilirlik düzeyi Kahramankazan, Çubuk, Gölbaşı ilçelerine kıyasla 5 kat fazladır. Nüfus, iş yeri sayısı, otomobil sayısı, çalışan nüfus gibi değişkenler ve erişebilirlik arasında yüksek pozitif ilişki varken hane halkı büyüklüğü, yüzölçümü gibi değişkenler ile yüksek negatif bir ilişki tespit edilmiştir. Sosyal gruplar bazında yapılan değerlendirme de ise Ankara kenti ulaşım altyapısının diğer sosyal gruplara kıyasla düşük gelir grubunun ihtiyaçlarına daha iyi cevap verebildiği görülmektedir.

ANAHTAR KELIMELER: Ankara, Erişebilirlik, Ulaşım

\section{GİRIŞ:}

İnsanlar, günlük hayatta gerçekleştirdikleri sosyo-ekonomik faaliyetlerden dolayı, çeşitli hizmetlere ihtiyaç duymaktadır. Bu çerçevede ihtiyaç duyulan en temel hizmetlerden birisi de ulaşım hizmetidir. Ulaşım, her ne kadar yolculuk yapma arzusunda olan insanların ve belirli ekonomik amaçlar çerçevesinde üretilen malların, bir noktadan başka bir noktaya aktarılmasını ifade etse de, son zamanlarda daha çok hizmet boyutu ile literatürde yerini almaktadır (Dell'Olio, Ibeas, ve Cecin, 2011). Ulaşım hizmetlerini sağlamada kullanılan araçların, tarih boyunca yaşanan teknolojik gelişmelerle birlikte, yüksek hız, kapasite vb. hizmet özellikleri açısından geniş bir çeşitliliğge sahip olduğu görülmektedir (Mokhtar, 2011). Ulaşım sistemleri, teknolojik imkânların gelişimine paralel bir şekilde ilerleme kaydetmektedir (Erdoğan, 2016). Gelişen teknolojiler, insanların bir noktadan bir diğer noktaya giderken hız, zaman, maliyet kavramlarında elde ettikleri kazancın artırılmasına yönelik katkı sağlamaktadır. Ulaşım teknolojilerindeki temel eğilim, ulaşımda geçen sürenin kısaltılması için yol altyapısı, araç türü vb. kavramlar üzerine araştırma ve geliştirme çalışmalarını merkeze almaktadır. Geliştirilen bu iki dinamik sayesinde insanların birim zamanda etkileşim içinde olduğu ve olabileceği mekân sayısı da doğru oranda artmaktadır. Kentlerdeki yapılaşmış alanların ve kentli nüfus yoğunluğunun hızlı ş̧ekilde artmasında otomobilin rolünü düşündüğümüzde, bu durum daha iyi anlaşılabilmektedir (Cervero, 2013). Ulaşım talebi, bir yolcunun veya malın ulaşmayı arzuladığı hedef noktasına, istediği taşıt türüyle, istenilen güzergâhta gidebilmesi olarak karşımıza çıkmaktadır. Söz konusu durum bir yere ulaşmak için önce o yerin erişebilir olmasını gerektirmektedir. Erişebilirlik kavramı ulaşım bağlamında değerlendirildiğinde, herhangi bir nedenden dolayı, iki mekân arasında gerçekleştirilmek istenen etkileşimi sağlayacak altyapıya yönelik mevcut bileşenler olarak ifade edilebilir. Ulaşımda erişebilirlik, bu perspektifte, iki noktayı birbirine bağlayan yollar ve ulaşım türleri olmak üzere iki kavramdan meydana gelmektedir. Ulaşım teknolojileri konusunda yaşanan gelişmelere baktığımızda, daha önce de ifade edildiği gibi ulaşım türlerinin birim zamanda daha fazla yol yapabilmesi için hız bağlamında, hayvanların kas gücünden, buhar, motor, elektrik sistemlerine gelişim; yol açısından ise patika, ray, asfalt, manyetik ray vb. sistemlere doğru uzanan bir gelişim olduğu görülmektedir. Gelinen noktada havanın da hava taksi, uçangöz (drone) vb. araçlar ile bir ulaşım yolu olarak kullanılma sıklığının artırılmaya çalışılması, insanların mekânlara erişebilirlik için gerek hız gerekse zaman anlamında daha üst seviye teknolojilere her zamankinden daha fazla gereksinim duyduğunun bir işareti olarak görülebilir.

Gereksinim duyulan erişebilirlik düzeyi ve bu düzeyin artışı, mekânlar arası etkileşime duyulan talebin zamanla yoğunlaşması sonucu karşımıza çıkmaktadır (Gündoğdu ve Uğuz, 2020). Bir diğer ifadeyle, iki mekân arasında ulaşım talebinin artması, mekânlar arası daha teknolojik bir ulaşım altyapısının yatırımını tetiklemektedir. Farklı mekânlar için farklı ulaşım taleplerinin olması günümüz kentlerinin kullanım alanlarını ortaya koymak için gerçekleştirilen arazi kullanım planlamasının bir sonucudur. Arazi kullanımı, kentin yerleşime uygun olan alanlarının 
kentli insan için uygun bir şekilde kullanılma arayışı olarak ifade edilebilir (Pan, Qi, Wu, Zhang ve Li, 2012). Arazi kullanımında her ne kadar alanlar ön planda yer alsa da, alanlar arasında dolaşımı sağlayan ana unsur olan karayolu, demiryolu, suyolu gibi ulaşım türleri de bir o kadar önemlidir. Bu türlerin önemi, kentli insanın ulaşım talebinin karşılanmasında iki mekân arası etkileşimi sağlayan önemli bir erişebilirlik kanalı olmasından kaynaklanmaktadır. Kentlerin arazi kullanım planlaması ile üretilen kullanım biçimleri arasında farklı şekil ve düzeyde ulaşım gerçekleşmektedir. Bir diğer ifadeyle, kentli insan gitmeyi istediği her yere gidebilmek için her zaman ve her yerde aynı tür ulaşım alternatifine sahip değildir. Örneğin toplu taşımanın hizmet vermediği bir yere veya toplu taşıma hizmetinin sağlanmadığı bir anda, bir noktadan diğer bir noktaya giderken ya otomobil, taksi vb. kullanmak ya da yürümek durumunda kalınacaktır. Kent içinde, farklı tür arazi kullanımları arasındaki ulaşım aktiviteleri de farklı erişebilirlik düzeyinde gerçekleşecektir. Arazi kullanım alanları arasında günlük aktivitelerin devamlılığını sağlamak amacıyla oluşturulan ulaşım kanalları ve kullanılan ulaşım türü alternatifi, kentlerin özelliğine ve kentin fiziksel yapısına göre çeşitlilik gösterebilir. Genel olarak günümüzde tüm kentsel ölçekler düşünüldüğünde kullanılan ulaşım türleri, bisiklet, otomobil, minibüs, otobüs, taksi, metrobüs, tramvay, hafif raylı sistem, ağır raylı sistem, teleferik, füniküler, uçak, gemi, feribot gibi sistemlerdir (Stenneth, Wolfson, Yu, ve Xu, 2011). Ancak ulaşım türlerinin kentsel ulaşım rutininde kullanılan formlarını genel başlıklarla ifade etmek gerekirse; lastik tekerlekli ulaşım türleri, raylı ulaşım türleri ve kablolu ulaşım türleri olarak gruplandırılabilir. Bu sistemler yararlandıkları teknolojilerden dolayı birbirinden farklılık göstermektedir.

Ulaşım sistemlerinin sahip olduğu teknoloji çeşitliliği, mekânlar arasında erişebilirlik düzeyi açısından farklılık oluşturmaktadır. Örneğin birim zamanda daha fazla yolcuyu bir noktadan bir diğer noktaya taşıyan yüksek kapasiteli sistemler, talebin yoğun olduğu yerlerde erişebilirlik açısından üst düzey kalite sağlayan sistemler olarak değerlendirilebilir.

\section{Teorik Arka Plan}

Erişebilirlik, kentin belirli noktalarına ulaşım türleriyle erişim düzeyi ve koşulları olarak tanımlanmaktadır (Kırmızı, Kolağasıŏlu ve Çalışkan, 2012:59). Keleş’e göre erişebilirlik (1998), bir taşınmaza, bir yerleşim yerine ya da bir yerleşim yerindeki kamusal hizmete erişme olanağı, varış kolaylığını ifade eder. Litman’a göre erişebilirlik (2012), çeşitli grup, insan, taşıt türü, mekân perspektifi kapsamında insanların mekânlar arasında etkileşimlerinin sorgulanmasına yarayan bir araç olarak değerlendirilmektedir. Erişebilirlik, etkileşim kurulacak firsatlara ulaşabilme potansiyeli olarak da tanımlanabilir (Hansen, 1959). Konuma dayalı tedbirler, bireyin ulaşmak istediği hedefe potansiyel erişimi olarak düşünülebilir. Erişebilirlikle ilişkili dört bileşen bulunmaktadır. Bunlar; Arazi kullanımı bileşeni, ulaşım bileşeni, zaman bileşeni ve bireysel bileşendir (Geurs ve Van Wee, 2004). Literatürde erişebilirliğin farklı bileşenleri üzerine yapılan çalışmalar bulunmaktadır. Arazi kullanımı bileşeni bağlamında, farklı konut alanlarında yaşayanların sağlık imkanına erişebilirliği (Campbell, Rising, Klopp ve Mbilo, 2019), ulaşım ve arazi kullanım ilişkisinin erişebilirlik üzerindeki etkisinin ölçülmesi (Avner ve Lall, 2016); ulaşım bileşeni bağlamında, yürüme-ara toplu taşımayı kullanma-otomobil kullanımı ile mesafe tabanlı erişebilirlik (Campbell, Rising, Klopp, ve Mbilo, 2019), kent merkezinde ve merkez çeperindeki iş yerlerine ulaşımda otomobilin ve toplu taşımanın erişebilirlik düzeyinin kıyaslanması (Quiros ve Mehndiratta, 2015), ulaşım sistemi yoksunluğu ve yüksek maliyetlerin oluşturduğu dezavantajın hane halklarının temel ulaşım faaliyetini gerçekleştirememe nedeniyle maruz kaldıkları sosyal dışlanma etkisinin belirlenmesi (Lucas, 2011); zaman bileşeni bağlamında, farklı ulaşım modları, destinasyon türleri ve yolculuk süresini de temel alan farklı erişebilirlik ölçütlerinin karşılaştırılması (McCahill, Jain ve Brenneis, 2020); bireysel erişebilirlik bileşeni bağlamında, yaşlıların ve engellilerin erişebilirliği (Hallgrimsdottir, Wennberg, Svensson ve Ståhl, 2016), toplu taşımaya erişim sorunu ve bunun sosyal dişlanma etkisinin mevcudiyeti konularında çalışmalar yapıldığı gözlenmiştir (Hallgrimsdottir, Svensson ve Ståhl, 2016). Bütün bu tanımlar değerlendirilerek erişebilirlik, ulaşımın mekânlar arasında kurduğu etkileşim bağının boyutu olarak tanımlanabilir. Dahası erişebilirlik, boyut olarak ulaşımın etkileşim bağının niteliksel ve niceliksel yönünü işaret etmektedir.

Erişebilirlik analizi ise, kentin belli noktalarına ulaşım türleriyle erişim düzeyi ve koşullarının bir örnekçe üzerinde değişik yöntemler kullanılarak sınanmasıdır (Kırmızı ve diğerleri, 2012). Yapılan bu tanımlar bağlamında erişebilirliğin, göreceli, yoruma açık, hesaplanma ve ifade edilme şekillerinin farklılık arz edeceği bir kavram olduğu görülmektedir. Ele alınış biçimi yönüyle kimi insanlar için erişebilir olan, kimi insanlar için erişebilir olmayabilir. (Tiznaido-Aitken, Muñoz ve Hurtubia, 2021). Erişebilirlikte temel yaklaşımlar sosyo-ekonomik alışkanlıkların insani ihtiyaçların giderilmesine odaklanmaktadır. Kişisel gereksinimlerin karşılanması için gerçekleştirilecek ulaşım 
aktivitelerindeki mevcut durumu analiz eder ve sorgular. Temel olarak insanların mekânlar arasındaki erişebilirliğini, taşıtlar, fiziksel mekân, yaş, cinsiyet, gelir düzeyi gibi bir takım değişkenler etkilemektedir (Litman, 2012). Günümüzde birçok uzman ve araştırmacı, erişebilirliğin ölçülmesine yönelik belirlenen ölçütleri, üstün performansın belirlenmesinde bir dayanak olarak görmektedir (Levine, Grengs ve Merlin, 2019; Litman, 2020). Erişebilirlik düzeyinin belirlenmesine yönelik yapılacak hesaplama yöntemleri, bize mekân ve insanlar arası etkileşimi işaret etmektedir. Erişebilirlik, Şenbil tarafından (2012) mekânın zaman bileşeni kapsamında yapılmak istenen aktivitelere erişim kalitesinin bir ölçüsü olarak açıklanmaktadır. Mekân ve mekâna erişim yöntemi olan ulaşım türleri, erişimin kalitesini şekillendiren unsurlardır. İnsanların birbirinden farklı nitelikte sosyo-ekonomik düzeye sahip olması, mekân etkileşimlerinin kalitesine doğrudan etki etmektedir. Üst gelir grubuna ait bir kişinin bir mekâna ulaşmak isterken kullanabileceği ulaşım alternatiflerinin, alt gelir grubuna ait bir kişinin ulaşım alternatiflerinden daha farklı ve çeşitli olması kaçınılmazdır.

Mekân, insanların sosyo-ekonomik ihtiyaçlarına farklı düzeylerde karşıllk vermektedir. İnsanla mekân arasındaki etkileşimde ulaşım gereksinimi, fiziksel olarak ya da taşıtlar vasıtasıyla gerçekleşmektedir. Günümüzde gelişmiş teknolojik imkânlar, ulaşım talebinin karşılanmasında insanların kullanımına çeşitli alternatifler sunmaktadır. Talepler, kimi zaman yakın mekânlar arasında, kimi zaman ise uzak mekânlar arasındaki yolculuklardan oluşmaktadır. Uzak mekânlar arası taleplerde ileri teknolojiye sahip taşıtlar etkin olarak kullanılmakta, yakın mekânlar arasında ise çoğunlukla fiziksel güç kullanılarak gerçekleştirilen bisiklet ve yaya yolculukları ön plandadır. Ulaşım sisteminin etkinlik düzeyi, yolculuk amacına ve talep çeşitliliğine cevap verebildiği ölçüde verimlidir. Bütün ulaşım sistemlerinin mekânlar arasında kurgulanmasını sağlamak, kaynakların korunması açısından doğal olarak olumlu karşılanmayacaktır. Bundan dolayı mekânlar genişledikçe sürdürülebilirlik çerçevesinde cevap verecek nitelik ve nicelikte yatırım (ulaşım arzı) sağlanmalıdır (Şimşek ve Yeşiltepe, 2020).

Nitelik ve niceliklerin düzeyi, ulaşım teknolojilerinin yapısına göre değişkenlik göstermektedir. Otomobil, dolmuş, otobüs, tramvay, metro ve banliyö gibi bazı ulaşım taşıtlarının, fiziksel, teknik, çevresel ve ekonomik anlamda birbirine üstünlüğü bulunmaktadır (Elker, 2012; Litman, 2020; Kahn Ribeiro ve diğerleri, 2012; Gourdin, 2006).

Toplam yolcu kapasitesi, saatlik yolcu kapasitesi, esneklik, fiziksel otonomi, hız, enerji tüketimi, konfor, işletme için alan gereksinimi gibi bir takım değişkenler ulaşım araçlarının fiziksel teknik yönünü oluşturmaktadır. Altyapı, kuruluş, kamusal ve kullanıcı maliyeti, kişi başı maliyet, ulusal kaynak tasarrufu gibi değişkenler ulaşım araçlarının ekonomik yönünü göstermektedir. Kaza olasılı̆̆ı, gürültü, görüntü ve çevresel kirlilik ise ulaşım taşıtlarının çevresel yönünü ifade etmektedir (Elker, 2012).

Mekânlar arasında gerçekleştirilen ulaşım aktivitelerinde, ekonomik, fiziki-teknik ve çevresel yönden avantajlara sahip ulaşım alternatifinin bulunması, üst düzey bir erişebilirliğin göstergesidir (Allen ve Farber, 2020). Özellikle, kent yönetimleri tarafından yatırım kararı alınırken, bahsi geçen bu yönler açısından elde edilecek faydalar, sıklıkla göz önünde bulundurulmaktadır. Genel olarak ulaşım ağında daha ileri teknoloji içeren sistemlerin kullanılması sonucunda, alan ihtiyacı, hız, kapasite, enerji tüketimi, işletme-yatırım maliyeti, yolcu sayısı-maliyet, çevre konularında daha fazla fayda elde edilmektedir. Örneğin otomobil, dolmuş, otobüs, tramvay seçenekleri değerlendirildiğinde aynı anda aynı miktarda yolcu taşınması hizmetini, 1 tramvay, 3 otobüs, 18 dolmuş, 250 otomobil sağlayabilmektedir. Bir diğer ifade ile 250 otomobilin taşıdığı yolcu sadece 3 otobüs tarafından taşınabilmektedir (Litman, 2020).

Benzer şekilde, hafif raylı sistem için tek yönde saatlik taşıma kapasitesi 40.000 yolcu olarak ifade edilirken bu rakam otobüslerde 12.000 yolcu, minibüs için 3.500 yolcu ve dolmuş için 1.500 yolcu olarak ifade edilmektedir. Mekânsal tüketim düşünüldüğünde, bisiklet kullanan 40 yolcuyu taşımak için toplamda 1 otobüsün rahatllkla yeteceği ifade edilebilir. Aynı 40 kişinin otomobil kullandığı düşünülürse bir otobüse kıyasla çok daha fazla mekân tüketimi gerçekleşmesi gündeme gelecektir (Litman, 2018). Enerji tüketimi, kişi başına birim olarak göz önünde bulundurulduğunda ise raylı sistemlerin otobüs, otomobil, dolmuş gibi sistemlere kıyasla bir üstünlüğü söz konusu olmaktadır. Ekonomik olarak değerlendirmede ise birim araçta yolcu sayısının daha fazla olması daha fazla fayda sağladığından raylı sistemlerin göreceli olarak üstün bir ulaşım sistemi olduğu anlaşılmaktadır.

Çevre konusunda özellikle emisyon üretimi nedeniyle oluşan hava kirliliği açısından raylı sistemlerin diğer türlere göre üstünlüğü bulunmaktadır. Aynı taşıt başına yolcu hesabı yapılarak otomobilin minibüse, minibüsün otobüse kıyasla daha fazla kirlilik oluşturduğu ifade edilmektedir. Ayrıca kaza olasılığı açısından ulaşım türleri ele 
alındığında, fiziksel özerklik açısından üstün olan sistemlerin kaza olasıllı̆ının daha fazla olduğunu söylemek mümkündür. Bu duruma karşılık olarak fiziksel üstünlüğü bulunmayan yani esnekliği olmayan raylı sistemlerde kaza olasılı̆ğ esnek sistemlere göre oldukça düşüktür. Kent dokusunda tarihi yapısı ön planda yer alan yerleşimlerde otomobillerin sayıca çok olması, yerleşimin kültürü üzerine hem gürültü hem de sera gazları salınımı açısından olumsuz bir imaj çizmektedir. Kent yönetimleri için raylı sistemler ise geniş mekân ve meydan düzenlemeleri için bir araç olarak kullanılabilmektedir. Çevre konusunda lastik tekerlekli ulaşım teknolojilerinin üstün olduğu tek yön, gürültü kirliliği olarak karşımıza çıkmaktadır (Tablo 1), (Elker, 2012, Litman, 2020; Planitmetro, 2014; Kahn Ribeiro, Figueroa, Creutzig, Dubeux, Hupe ve Kobayashi, 2012; Gourdin, 2006).

Tablo 1. Ulaşım Türlerinin Nicelik ve Nitelik Yönünden Karşılaştırılması

\begin{tabular}{ccccc}
\hline Nicelik ve Nitelikler & Otomobil & Dolmuş & Otobüs & Raylı Sistem \\
\hline Aynı sayıda yolcu için gereken alan & 250 otomobil & 18 minibüs & 3 otobüs & 1 (tramvay dizisi) \\
Kapıdan kapıya servis & Bazen & Bazen & Bazen & Bazen \\
Esneklik & Yüksek & Yüksek & Orta & Düşük \\
Fiyat & Yüksek & Orta & Orta & Düşük \\
Konfor & Yüksek & Orta & Orta & Yüksek \\
Kapasite (Yolcu/Saat/Hat) & 1.500 & 3.500 & 12.000 & 40.000 (metro) \\
$\begin{array}{c}\text { Enerji Tüketimi (Km Başına Yolcu) } \\
\text { Yatırım ve İşletme Maliyeti } \\
\text { (bir kişiyi bir km taşıma) }\end{array}$ & 100 & 26 & 19 & 19 (metro) \\
$\mathrm{CO}_{2}$ eşdeğer kirliliği (gram/taşıt-km) & 143 (Dizel) & 50 & 15 Birim & 10 Birim (HRS) \\
Kaza Riski & Çok Yüksek & Yüksek & Orta & Çok Düşük
\end{tabular}

Kaynak: Elker, 2012; Litman, 2020; URL-1, 2020; Kahn Ribeiro ve diğerleri., 2012; Gourdin, 2006.

Ulaşım teknolojileri göz önünde bulundurulduğunda, raylı sistem ve minibüsün etkin kullanıldığı bir ulaşım etkileşiminde farklılıklar şu şekildedir. Raylı sistem esnek olmayan bir güzergâhta ilerleyeceği için minibüse kıyasla kaza yapma riski daha düşük, ücret ödeme sistemi daha düzenli ve sabit zamanlı ulaşım hizmeti sunma avantajı vardır. İstasyon açısından daha korunaklı ve temiz bir altyapıya sahiptir. Konfor açısından bakıldığında, oturarak yolculuk yapabilme, trafikten izole daha sessiz bir yolculuk geçekleştirebilme, sefer aralıklarına uygun hareket edebilme, yolculuk hakkında anlık bilgi edinebilme, kalkış aralıklarının kısa olması, işletime başlama ve sonlanma saatinin daha uzun olması gibi çeşitli imkânlara sahiptir. Birim başına taşınan yolcu kapasitesi düşünüldüğünde çok daha ekonomiktir. Ulaşım taşıtlarının teknolojik özelliklerine göre karşılaştırması yapıldığında, raylı sistemlerin otobüslere, otobüslerin minibüslere, minibüslerin de otomobillere karşı birim başına karbondioksit üretimi, kapasite, yolcu-km başına enerji tüketimi açısından üstün olduğu görülmektedir (Şekil 1), (Elker, 2012; Gourdin, 2006). 


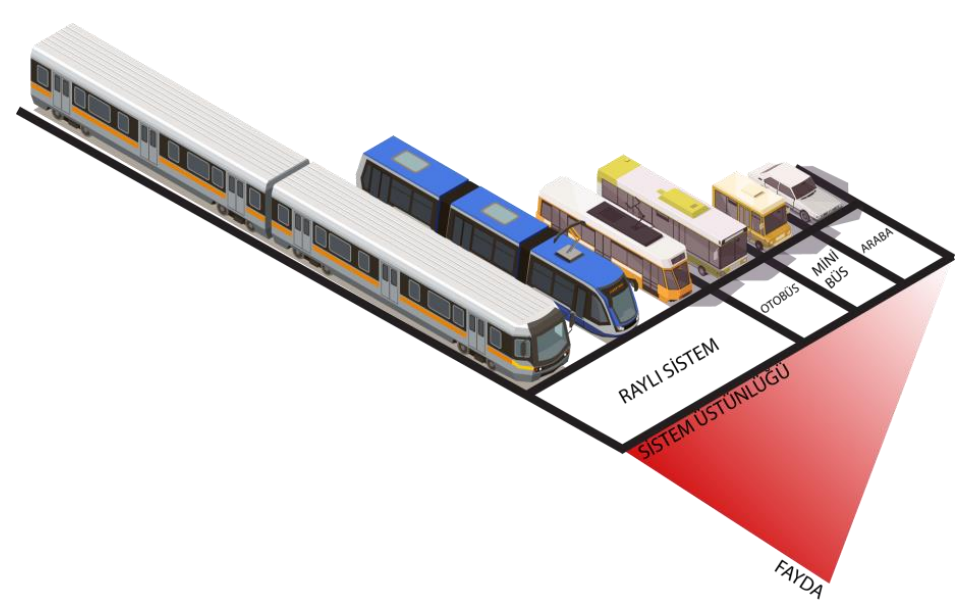

Şekil 1. Sistem Üstünlüğünün Karşılaştırılması Kaynak: Macrovector/Freepik, 2020

Ulaşım alternatiflerinin çeşitli olması, birim zamanda yapılacak ulaşım faaliyetinin etkin bir şekilde gerçekleşebilme ihtimalini artırmaktadır. Bu ihtimalin yüksek olması da, erişebilirliğin üst düzey olduğu daha kaliteli bir ulaşım ağının varlığını yansıtır. İki nokta arasında geçekleştirilecek ulaşım faaliyetinin kalitesi, hem teknolojiden hem de imkânların sayısından etkilenmektedir. Bu durumda ulaşım faaliyetlerinin kalitesine bağlı olarak erişebilirlik kavramının yeni yorumu, mekânlar arasında etkileşim sağlayan ulaşım türlerinin niceliksel ve niteliksel özelliklerine bağlı olarak, kullanıcının ulaşımda erişim ihtiyacını karşılayabilme düzeyi, şeklinde olacaktır. Bu yeni tanıma göre erişebilirlik kavramının niceliksel ve niteliksel erişebilirlik adında iki bileşeni ortaya çıkacaktır.

Nicelik kavramı erişebilirlik açısından iki mekân arasında ulaşım ihtiyacını gidermeye yönelik olarak kullanılmaya hazır araç sayısını, mesafe, hat sayısı gibi ölçülebilir, sayılabilir değişkenleri ifade eder. Örneğin, iki nokta arasında ulaşım hizmeti sağlayacak 2 hat bulunması ve bu hatta 10 otobüs, 3 dolmuş işletilmesi, noktalar arası mesafenin $6 \mathrm{~km}$ olması gibi sayısal değişkenler miktar bildirdiğinden erişebilirliğin niceliğ̣i, azlık-çokluk yönü tarif edilmektedir. Nitelik kavramı nicelik kavramından farklı olarak iki mekân arasında ulaşım ihtiyacını gidermeye yönelik olarak kullanılmaya hazır araçların özellikleri, araçların kullandığı yol-hat özelliklerini belirtmektedir. Örneğin, iki nokta arasında ulaşım hizmetinin otobüsle sağlanması, raylı sistemler ile sağlanmasından fiziksel, teknik, çevresel ve ekonomik açılardan farklılık arz etmektedir. Bir diğer ifade ile erişebilirliğin niteliği, özellik yönü tarif edilmektedir. Hizmet farklılığı, araçların nitelik, yani özelliklerinden kaynaklanmaktadır.

Erişebilirlik tanımının ilk bileşeni niceliksel erişebilirlik olup, mekânlar arası ulaşım faaliyetlerinde sahip olunan aynı türden alternatiflerin sayısını kapsamaktadır. Birinci durumda A ve B mekânları arasında aynı türden 8 ulaşım alternatifi ve ikinci durumda A ve B mekânları arasında aynı türden 4 ulaşım alternatifi olduğu başka bir durum düşünüldüğünde, A ve B mekânları arasındaki erişebilirlik düzeyinin, ilk durumda niceliksel erişebilirlik anlamında daha üst düzeyde olduğu düşünülebilir (Şekil 2).
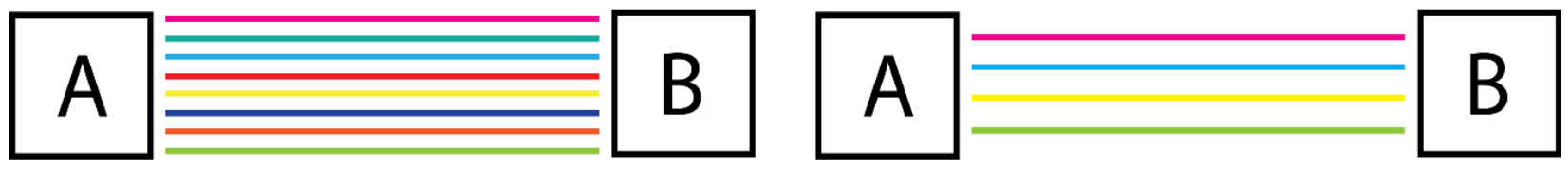

\section{Şekil 1. Erişebilirlikte Nicelik}

Erişebilirlik tanımının ikinci bileșeni niteliksel erişebilirlik olup, mekânlar arası ulaşım faaliyetlerinde sahip olunan farklı alternatiflerin türe ait özelliklerini ifade eder. Alternatiflerin niteliğinden kaynaklanan niteliksel erişebilirlik ulaşım taşıtlarında oturma imkânının olması, güvenlik, kaza olasılığı, trafikten bağımsızlık, maliyet gibi teknolojik özelliklerinin sağladığı avantajları ifade eder. A ve B mekanları arasında 4 metro hattının işletildiği bir senaryo, 4 otobüs hattının işletildiği bir senaryoya göre niteliksel erişebilirlik anlamında üstündür (Şekil 3). 


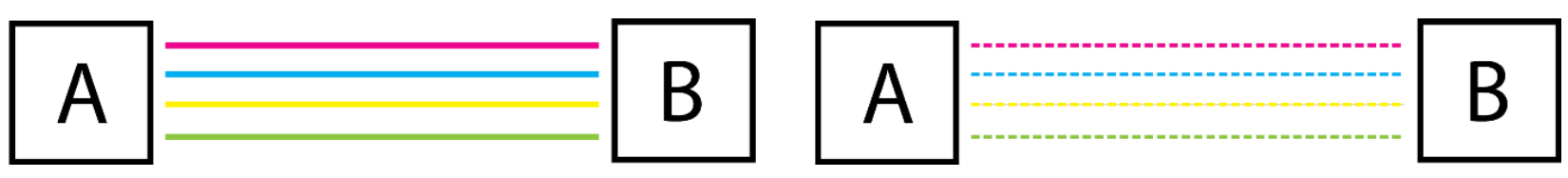

Şekil 3. Erişebilirlikte Nitelik

Şekil 4'te verilen örnek diyagramda erişebilirliğin niceliksel ve niteliksel yönü çizimle ifade edilmektedir. A ve B mekânları arasında 3 farklı ulaşım alternatifinin olduğu (düz çizgi, kesikli çizgi, iki noktalı kesikli çizgi) ve aynı ulaşım türüne ait 2 farklı hat alternatifinin olması durum, I numaralı kısımda gösterilmektedir. II numaralı kısımda ise 1 ulaşım alternatifinin 2 farklı hat alternatifi gösterilmektedir. Bu gösterim türü erişebilirlik değerlendirme diyagramı adı verilerek geliş̧tirilmiştir. Erişebilirlik değerlendirme diyagramında iki mekân arası ulaşım türleri farklı çizgi stili ile gösterilir. Aynı türe ait farklı hatlar ise aynı çizgi stilinde farklı renklerle gösterilir. Aynı renkler aynı güzergâhtan iki farklı teknolojiye sahip taşıtın geçtiğini göstermektedir. Diyagramda I durumunda A ve B mekânları arası 3 farklı teknolojiye sahip ulaşım sistemi senaryosu gösterilmektedir. İki farklı teknolojinin birer hattı aynı güzergâh üzerinde ilerlemektedir. I durumunda mekânlar arasında toplamda 3 farklı ulaşım taşıtı türü imkânı ve 4 güzergâh alternatifi bulunmaktadır. II durumunda mekânlar arasında toplamda tek ulaşım türü alternatifi (Ör: Otobüs) ve 2 güzergâh alternatifi bulunmaktadır (Şekil 4).

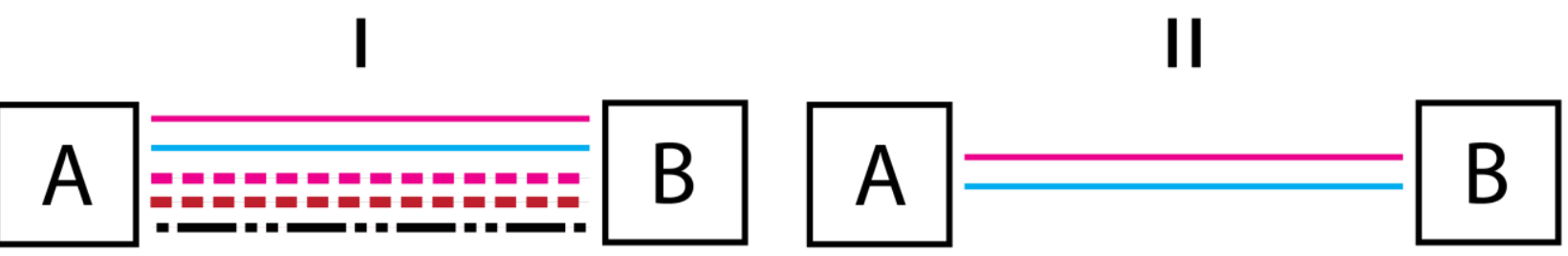

Şekil 4. Erişebilirlik Değerlendirme Diyagramı

Şekil 4 'teki diyagramda görüleceği üzere iki mekân arasında ulaşımın erişebilirlik yönünden niceliksel ve niteliksel kalitesi sorgulandığında, I senaryosunun gerek alternatif sayısı açısından gerekse hat sayısı fazlalığından dolayı II senaryosuna göre teorik açıdan üstünlüğü söz konusudur. Geliştirilen erişebilirlik tanımının nitelik ve nicelik yönünden ortaya koyulduğu çerçevede çok fazla türde ve aynı türün çok sayıda ulaşım hizmeti sağlayan aracının yer aldığı kentlerde, erişebilirlik düzeyinin daha kolay ş̧ekilde belirlenebileceği öngörülmektedir.

\section{2. Çalışma Alanının Belirlenmesi}

$\mathrm{Bu}$ çalışma kapsamında, kentsel ulaşımda erişebilirliğin nicelik ve nitelik özellikleri, Ankara metropoliten alanı üzerinden incelenmektedir. Ankara bugün 5.639.076 kişilik nüfusa sahiptir (TÜíK, 2019). Bu nüfusun \%80'i metropoliten alan içinde yaşamaktadır (2023 hedefli Ankara Nazım Planı, 2006). Metropoliten alan, Ankara ilçelerinin büyük bir bölümünü kapsamaktadır. Ankara Büyükşehir Belediyesi, metropoliten alan odak olmak üzere il sınırlarını da kapsayacak şekilde, Ankara kentinin ulaşım alanındaki bazı yatırımlarını gerçekleştiren ve ulaşım sistemlerini yöneten kamu kurumudur. Ankara kenti, metropoliten alanda çeşitli kamusal ulaşım türlerinin varlığını taşımaktadır (Gökalp, 2019). Bu kamusal ulaşım türlerinin bir kısmı metropoliten alanda yer alan ilçeler arasında hizmet verirken, bir kısmı ise ilçelerin kendi içinde hizmet vermektedir. İlçeler arasında hizmet sağlayan toplu ulaşım türleri arasında dolmuş, otobüs, metro, banliyö gibi araçlar bulunmaktadır (Şekil 5, Şekil 6). 


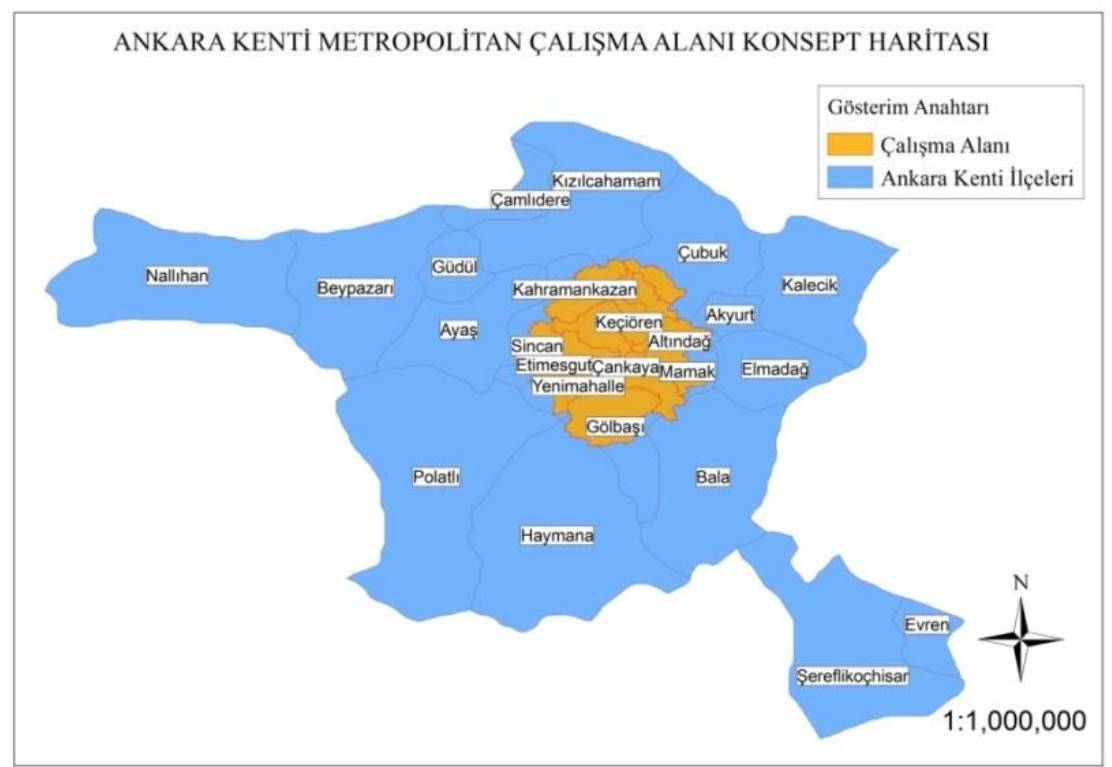

Şekil 5. Ankara Kenti ve Metropoliten Çalışma Alanı Konsept Haritası

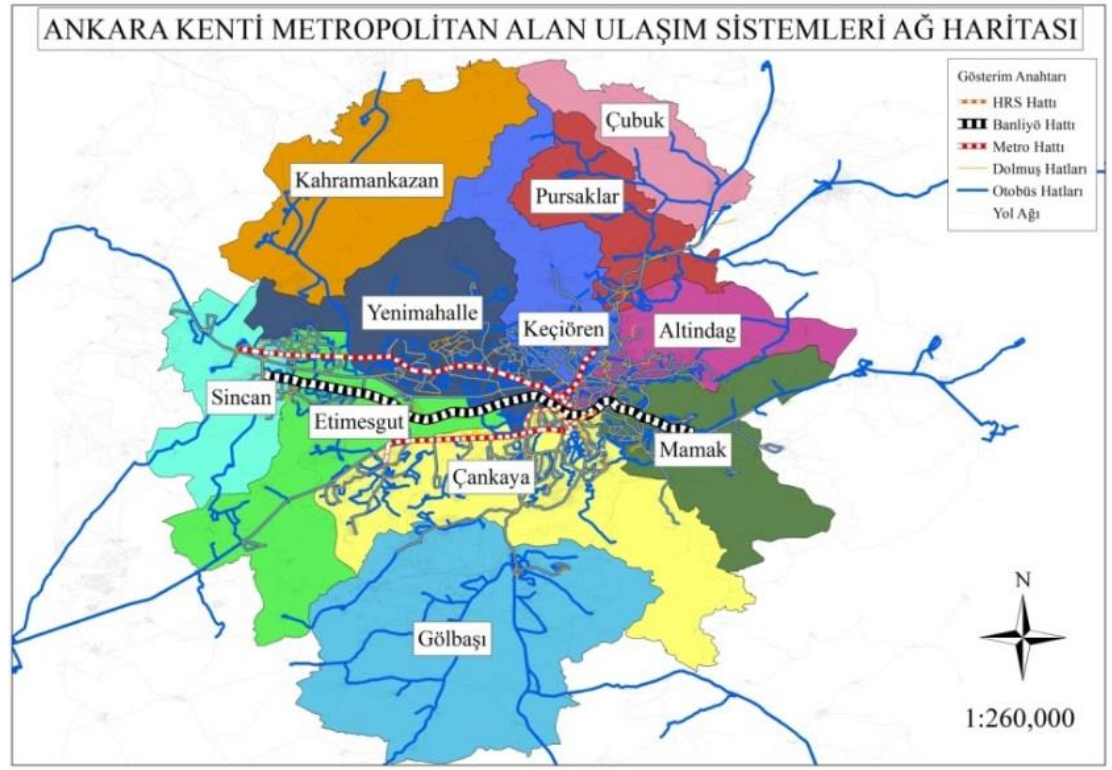

Şekil 6. Ankara Kenti ve Metropoliten Alan Ulaşım Sistemleri A $\breve{g}$ Haritası

Ankara metropoliten alanının arazi kullanım yapısı incelendiğinde, kent merkezinin ağırlıklı olarak tarihi ve ticari merkez vasfina sahip iki merkezin birleşiminden ve çoğunlukla Merkezi İş Alanı (MİA) niteliği taşıyan bir yapıda olduğu görülmektedir. MİA çevresinin konut alanları ve sosyal donatı alanları ile çevrelendiği görülmektedir. İlçe merkezleri alt merkez görevi görmektedir ve her bir ilçe merkezinde yoğun ticari kullanımlar, iş-çalışma alanları, sosyal donatı alanları ve kentsel hizmet birimleri yer almaktadır. Dolayısıyla tahmin edileceği üzere ağırlıklı olarak konut alanlarından ilçe merkezlerine ve kentin çekirdeği konumundaki MİA'ya yönlenen çalışma ve sosyo-ekonomik faaliyetlerin gerçekleşmesini sağlayacak ulaşım talebinin akışı söz konusu olmaktadır. 
Çalışma kapsamında, farklı sosyo-ekonomik nitelikleri ve farklı ulaşım altyapılarına sahip olması nedeniyle, kentin merkezi niteliğe sahip ilçeleri, dolayısıyla Ankara'nın merkez ilçe özelliği gösteren ilçelerinin ulaşım konusunda sahip olduğu erişebilirlik kalitesi düzeyine yönelik karşılaştırmalı inceleme yapmaya olanak vermektedir. Bu durumda sonuç olarak hangi ilçelerin erişebilirlik açısından üst düzeyde olduğu, hangi ilçelerin alt düzeyde olduğu, hangi ilçelerin ulaşım yatırımına sosyo-ekonomik açıdan daha fazla ihtiyaç duyduğu gibi sorulara cevap üretilebilecektir.

İnsanlar, hangi ulaşım türünü seçerse seçsin, yolculuklarına her zaman yürüyüşle başlar ve bitirirler (Stjernborg, Emilsson ve Ståhl, 2014). Bu nedenle erişebilirlikte en fazla kullanılan ulaşım türü yaya olduğu için bu çalışma kapsamında yaya hariç diğer ulaşım türleri ile erişebilirliğin ölçülmesine yönelik bir yaklaşım benimsenmiştir.

\section{Metodoloji ve Veri Analizi}

Çalışma kapsamında geliştirilen yeni metodoloji için Ankara kenti metropoliten alanında seçilen ilçeler arasında hizmet veren ulaşım türlerinin niceliksel ve niteliksel özellikleri ön planda yer almaktadır. İlçeler arası mevcut ulaşım altyapısına ilişkin veriler toplanmıştır. Bu veriler otomobil için ilçeler arası mesafe, dolmuş ve raylı sistem için aktarmalı ya da doğrudan bir noktadan başka bir noktaya gidebilme, otobüs için ise hat sayılarının incelenmesi şeklindedir. Teknolojik anlamda çalışma alanında değerlendirmeye alınan ulaşım türleri sırasıyla otomobil, minibüs, otobüs, metro, hafif raylı sistem, banliyö şeklindedir.

Çalışma alanı sınırı oluşturulurken, Ankara metropoliten alan sınırı göz önünde bulundurularak, ulaşım planlama çalışmalarında genellikle ilçe sınırları çerçevesinde kalan hiperzone düzeyine eşit sınırlar oluşturulmaya çalışılmıştır. $\mathrm{Bu}$ bağlamda yapılan analiz, ulaşım düzeyine ilişkin genel bir fikir verebilecektir. Sınırlardan çok sınırların temsil ettiği ilçeler ve ilçelere ulaşım sağlayan ana aksları kapsayan geniş alanlar göz önünde bulundurulmuştur.

Uygulanan metotta, çalışma alanında var olan ulaşım türleri ve bu türlerin sayılarına ilişkin tespitler, Ankara Büyükşehir Belediyesi'nin EGO Genel Müdürlüğü web sayfalarından ve EGO Şehir İçi Bilgi Sistemi'nden elde edilmiştir. Otomobil ile erişebilirliğine ilişkin değerlendirmede, Google Earth vasıtasıyla iki nokta arasındaki mesafe ölçülerek, ilçeler arası doğrudan veya aktarma olarak dolmuş ile yapılan yolculuklara ilişkin ise Ankara Büyükşehir Belediyesi Ulaşım Planlama ve Koordinasyon Hizmetleri Şube Müdürlüğü’nden bilgi elde edilmiştir.

Dolmuşların otobüs ve raylı sistem gibi kamusal ulaşım sistemlerinden farklı değerlendirilmesinde, kesin şekilde belirlenmiş bir güzergâhı ve duraklama yerlerinin bulunmaması etkili olmaktadır. Her ne kadar otomobil açısından irdelendiğinde iki nokta arasında ulaşımı sağlayacak birden çok alternatif olsa da, insanlar genellikle maliyeti en ucuz olan ulaşım türünü ve en kısa yolu tercih etme eğilimindedir. Çalışma kapsamında otomobillerin erişebilirliğine ilişkin değerlendirme yapılırken bu durum göz önünde bulundurularak, ilçelerin erişebilirlik düzeyinin belirlenmesinde ilçelerin birbirilerine yakınlıkları temel alınmıştır. Geliştirilen bu çalışma kapsamında uygulanan metot 8 aşamadan oluşmaktadır. Bu aşamalar sırası ile şu şekildedir;

1. aşamada, öncelikle ilçeler arası mevcut ulaşım türleri kodlanır. Bu kodlamada harf karmaşasını önlemek amacıyla ulaşım türlerinin İngilizce baş harfleri verilebilir.

Otomobil $=\mathrm{C}$, Minibüs $=\mathrm{J}$, Otobüs $=\mathrm{B}$, Hafif Raylı Sistem $=\mathrm{L} \ldots . . \mathrm{x}=\mathrm{N}$

2. aşamada, kodlanan ulaşım türleri erişebilirlik nitelik ve niceliği açısından daha az nitelikli olandan en çok nitelikli olana doğru sıralanıp en düşükten, en yükseğe olacak şekilde puanlanır.

Otomobil=1, Minibüs=2, Otobüs=3, Hafif Raylı Sistem=4....X=Q

3. aşamada, düşük niteliğe sahip ulaşım türünden başlanarak tüm ulaşım türleri için tüm ilçeler arasında $(a, b, c, d, e$, ..., $\mathrm{n}$ inci ilçe) bu ulaşım türünü kullanan ilçeleri gösteren bir matris oluşturulur. Otomobil için bu matris ilçeler arası mesafe, düzensiz güzergâhı olan sistemler için ise doğrudan ve dolaylı erişebilirliğe göre tamamlanır. Bu matriste ulaşım türü taban, incelenen ilçe adı ise alt indis olarak belirtilir. Çalışma alanında A ve B noktaları arasında örneğin 20 hat ile hizmet sağlansa dahi bütün hatların başlangıcı ilçe içinden olmayabilir. Bu durumdan dolayı eğer iki ilçe arasında daha detaylı inceleme yapılmak istenirse matris başlangıç ve bitiş başlıkları ile ikiye ayrılabilir (Tablo 2). 
Tablo 2. Yerleşimlerin Ulaşım Türleri Matrisinin Oluşturulması

\begin{tabular}{|c|c|c|c|c|c|c|c|c|c|c|c|c|}
\hline Car & \multicolumn{12}{|c|}{ Bitiş } \\
\hline \multirow{12}{*}{ 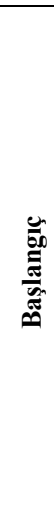 } & İLÇELER & $\overline{C_{a}}$ & $\overline{C_{b}}$ & $\overline{C_{c}}$ & $\overline{C_{d}}$ & $\overline{C_{e}}$ & $C_{f}$ & $\overline{C_{g}}$ & $\overline{C_{h}}$ & $\overline{C_{k}}$ & $C_{\text {. }}$ & $\overline{C_{n}}$ \\
\hline & $C_{a}$ & & & & & & & & & & & \\
\hline & $C_{b}$ & & & & & & & & & & & \\
\hline & $C_{c}$ & & & & & & & & & & & \\
\hline & $C_{d}$ & & & & & & & & & & & \\
\hline & $C_{o}$ & & & & & & & & & & & \\
\hline & $C_{f}$ & & & & & & & & & & & \\
\hline & $C_{g}$ & & & & & & & & & & & \\
\hline & $C_{h}$ & & & & & & & & & & & \\
\hline & $C_{k}$ & & & & & & & & & & & \\
\hline & $C_{\text {an }}$ & & & & & & & & & & & \\
\hline & $C_{n}$ & & & & & & & & & & & \\
\hline
\end{tabular}

4. aşamada, a, b, c, d, e, ...n’e kadar sıralanmış ilçelerin sahip olduğu değişkenlerin matrise girilmiş değerleri, ilçe bazında ayrı ayrı toplanır. Bir ilçenin hem başlangıç satırı hem de bitiş sütununda ilçeler arasında elde edilen değerlerin toplamı, o ilçenin ilgili ulaşım türü konusunda sahip olduğu toplam niceliği ifade etmektedir (Tablo 3).

Tablo 3. Erişebilirlik Seviyesi Nicelik Değerlerinin Hesaplanması

\begin{tabular}{|c|c|c|c|c|c|c|c|c|}
\hline Car & \multicolumn{8}{|c|}{ Bitiş } \\
\hline \multirow{8}{*}{ 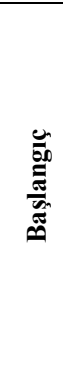 } & ILCÇELER & $C_{a}$ & $C_{b}$ & $C_{c}$ & $C_{d}$ & $C_{\ldots}$ & $C_{\mathrm{m}}$ & TOPLAM \\
\hline & $C_{a}$ & & $C_{a \mathrm{a}}+C_{\mathrm{b}}$ & $C_{\mathrm{ad}}+C_{\mathrm{c}}$ & $C_{\text {ad }}+C_{d}$ & $C_{\mathrm{ax}}+C_{-}$ & $C_{a}+C_{m}$ & $\mathrm{n}\left(C_{a}\right)+\sum_{k=a}^{n} C_{k}$ \\
\hline & $C_{b}$ & $C_{\mathrm{b}}+C_{a}$ & & & & & & \\
\hline & $C_{c}$ & $C_{c}+C_{a}$ & & & & & & \\
\hline & $C_{d}$ & $C_{d d}+C_{a}$ & & & & & & \\
\hline & $C_{\ldots}$ & $C_{m}+C_{a}$ & & & & & & \\
\hline & $C_{m}$ & $C_{\mathrm{m}}+C_{\mathrm{a}}$ & & & & & & \\
\hline & TOPLAM & ${ }_{\mathrm{n}}\left(C_{a}\right)+\sum_{k=a}^{n} C_{k}$ & & & & & & \\
\hline
\end{tabular}

a ilçesinin $C$ ulaşım türündeki toplam niceliği $=C_{a b}+C_{a c}+C_{a d}+C_{a e}+\ldots C_{a n}+C_{b a}+C_{c a}+C_{d a}+C_{e a}+\ldots C_{n a}$ şeklindedir. $\mathrm{Bu}$ aşamada bu hesap bütün ilçeler için yapılır. 5. aşamada, her ilçe için yapılan hesaplamalardan elde edilen değerler, yeni oluşturulan yerleşimler ve ulaşım türleri matrisinde yerine yazılır (Tablo 4).

Tablo 4. Yerleşimlerde Ulaşım Türlerine Göre Erişebilirlik Seviyesi Nicelik Değerlerinin Hesaplanması

\begin{tabular}{|c|c|c|c|c|}
\hline Ulaşım Türleri & a Yerleşimi & b Yerleşimi & $\ldots$ & n. Yerleşim \\
\hline $\mathbf{C}$ & $\mathrm{C}_{\mathrm{ab}}+\mathrm{C}_{\mathrm{ac}}+\mathrm{C}_{\mathrm{ad}}+\mathrm{C}_{\mathrm{ae}}+\ldots \underset{\mathrm{C}_{\mathrm{na}}}{\mathrm{C}_{\mathrm{an}}}+\mathrm{C}_{\mathrm{ba}}+\mathrm{C}_{\mathrm{ca}}+\mathrm{C}_{\mathrm{da}}+\mathrm{C}_{\mathrm{ea}}+\ldots$ & $\begin{array}{c}\mathrm{C}_{\mathrm{ba}}+\mathrm{C}_{\mathrm{bc}}+\mathrm{C}_{\mathrm{bd}}+\mathrm{C}_{\mathrm{be}}+\ldots \mathrm{C}_{\mathrm{bn}}+\mathrm{C}_{\mathrm{ab}}+\mathrm{C}_{\mathrm{cb}}+ \\
\mathrm{C}_{\mathrm{db}}+\mathrm{C}_{\mathrm{eb}}+\ldots \mathrm{C}_{\mathrm{nb}}\end{array}$ & $\ldots$ & $\ldots$ \\
\hline $\mathbf{J}$ & $\mathrm{J}_{\mathrm{ab}}+\mathrm{J}_{\mathrm{ac}}+\mathrm{J}_{\mathrm{ad}}+\mathrm{J}_{\mathrm{ae}}+\ldots \mathrm{J}_{\mathrm{an}}+\mathrm{J}_{\mathrm{ba}}+\mathrm{J}_{\mathrm{ca}}+\mathrm{J}_{\mathrm{da}}+\mathrm{J}_{\mathrm{ea}}+\ldots \mathrm{J}_{\mathrm{na}}$ & $\begin{array}{c}\mathrm{J}_{\mathrm{ba}}+\mathrm{J}_{\mathrm{bc}}+\mathrm{J}_{\mathrm{bd}}+\mathrm{J}_{\mathrm{be}}+\ldots \mathrm{J}_{\mathrm{bn}}+\mathrm{J}_{\mathrm{ab}}+\mathrm{J}_{\mathrm{cb}}+\mathrm{J}_{\mathrm{db}}+\mathrm{J}_{\mathrm{eb}}+ \\
\ldots \mathrm{J}_{\mathrm{nb}}\end{array}$ & $\ldots$ & $\ldots$ \\
\hline B & $\ldots$ & $\ldots$ & $\ldots$ & $\cdots$ \\
\hline $\mathbf{L}$ & $\ldots$ & $\ldots$ & $\ldots$ & $\ldots$ \\
\hline $\mathbf{M}$ & $\ldots$ & $\ldots$ & $\ldots$ & $\ldots$ \\
\hline$\vdots$ & $\cdots$ & $\cdots$ & $\cdots$ & $\cdots$ \\
\hline $\mathbf{n}$ & $\cdots$ & $\cdots$ & $\cdots$ & $\cdots$ \\
\hline
\end{tabular}

6. aşamada, ulaşım türleri bazında ayrı ayrı hesaplanan değerlerde yerleşimler bazında kolayca karşılaştırmalı değerlendirme yapmak üzere standardizasyon yapılır. Standardizasyon her bir ulaşım türü için ayrı ayrı yapılır, en 
yüksek puanı elde eden yerleşim en yüksek (100) değerini alır, diğer yerleşimlerin standart puanı ise hesaplanmış değerinin en yüksek değerine bölünmesi ile bulunur.

7. aşamada, yerleşimlerin ulaşım nicelikleri bazında elde ettikleri standart değerler başta belirlenen nitelik katsayısı ile çarpılır (Tablo 5).

Tablo 5. Erişebilirlik Seviyesi Nitelik Standardizasyon Değerinin Hesaplanması

\begin{tabular}{|c|c|c|c|c|}
\hline Ulaşım Türleri & a yerleşimi & b yerleşimi & $\ldots$ & n. yerleşim \\
\hline $\begin{array}{c}\text { C }[\text { Nitelik } \\
\text { Katsayısı=1] }\end{array}$ & $\begin{array}{l}\text { (a Yerleşimi Standardize C Nicelik } \\
\text { Değeri)*1 }\end{array}$ & $\begin{array}{c}\text { (b Yerleşimi Standardize C } \\
\text { Nicelik Değeri)*1 }\end{array}$ & $\ldots$ & $\cdots$ \\
\hline $\begin{array}{c}\mathrm{J}[\text { Nitelik } \\
\text { Katsayıs! }=2]\end{array}$ & $\begin{array}{c}\text { (a Yerleşimi Standardize J Nicelik } \\
\text { Değeri)*2 }\end{array}$ & $\begin{array}{c}\text { (b Yerleşimi Standardize J } \\
\text { Nicelik Değeri)*2 }\end{array}$ & $\cdots$ & $\cdots$ \\
\hline $\begin{array}{c}\text { B [Nitelik } \\
\text { Katsayısı=3] }\end{array}$ & $\begin{array}{c}\text { (a Yerleşimi Standardize B Nicelik } \\
\text { Değeri)*3 }\end{array}$ & $\begin{array}{c}\text { (b Yerleşimi Standardize B } \\
\text { Nicelik Değeri)*3 }\end{array}$ & $\cdots$ & $\cdots$ \\
\hline $\begin{array}{c}\text { L [Nitelik } \\
\text { KatsayısI }=4]\end{array}$ & $\begin{array}{c}\text { (a Yerleşimi Standardize L Nicelik } \\
\text { Değeri)*4 }\end{array}$ & $\begin{array}{c}\text { (b Yerleşimi Standardize L } \\
\text { Nicelik Değeri)*4 }\end{array}$ & $\cdots$ & $\cdots$ \\
\hline$\vdots$ & $\ldots$ & $\cdots$ & $\cdots$ & $\cdots$ \\
\hline $\begin{array}{c}\mathbf{N} \\
\text { Nitelik } \\
\text { Katsayısı = q] }\end{array}$ & $\begin{array}{l}\text { (a Yerleşimi Standardize n türü } \\
\text { Nicelik Değeri)*q }\end{array}$ & $\begin{array}{l}\text { (b Yerleşimi Standardize } \mathrm{n} \\
\text { türü Nicelik Değeri)* } \mathrm{q}\end{array}$ & $\cdots$ & $\cdots$ \\
\hline
\end{tabular}

8. aşamada, verilen işlem bütün yerleşimler kapsamında yapıldıktan sonra her yerleşimin elde ettiği değerler toplanır. İlçe bazında özet bir tablo olarak verilir. Bu adımda elde edilen tabloda yüksek puana sahip olan yerleşimler, nitelik açısından daha üst düzey teknolojiye sahip sistemlerden oluşmaktadır. Ayrıca nicelik açısından ise ulaşım etkileşimleri için daha fazla sayıda alternatifi bünyesinde barındırmaktadır.

Geliştirilen yöntemin çalışma alanı kapsamında uygulaması ve sonuçları şu şekildedir;

Çalışma alanı olan Ankara kenti metropoliten alanındaki seçilmiş ilçelerde kullanılan ulaşım türlerinin kodları;

- $\quad$ Otomobil-Car= C

- $\quad$ Minibüs/Dolmuş-Jitney $=\mathrm{J}$

- Otobüs-Bus =B

- Hafif Raylı Sistem-Light Rail Transit=L

- $\quad$ Metro = M

- $\quad$ Banliyö-Suburban Train =S, olarak belirlenmiştir.

Kodlanan ulaşım türleri erişebilirlik nitelik ve niceliği açısından en az nitelikli olandan en yüksek nitelikli olana doğru sıralanıp en az nitelikli olana en düşük, en çok nitelikli olana en yüksek olacak şekilde puanlama yapılmaktadır. Fiziksel, teknik, çevresel ve ekonomik açıdan otomobilin ulaşım türleri içinde daha az niteliğe sahip olduğu görülmektedir. Niteliğinin lastik tekerli sistem ve raylı sistem üstünlüğüne kıyasla düşük düzeyde olmasından dolayı otomobil bu çalışma kapsamında düşük puan ile değerlendirilmektedir. Çalışma kapsamında yaya (1) ve bisiklet (2) değerleri hariç tutularak bir değerlendirme yapılmakta, Hafif Raylı Sistem, Metro ve Banliyönün aynı düzeyde puanlanması uygun görülmüştür. Raylı ulaşım türlerinin tamamı bir sistem olarak değerlendirilmek istendiğinden tüm raylı sistemlerin katsayısı eşit alınmaktadır.

- $\mathrm{C}=3$,

- $\mathrm{J}=4$,

- $\mathrm{B}=5$,

- $\mathrm{L}=6$,

- $\mathrm{M}=6$,

- $\mathrm{S}=6$, olarak belirlenmiştir. 
Düşük nitelikli ulaşım türünden başlanarak tüm ulaşım türleri için tüm ilçeler arasında (a, b, c, d, e, ..., n. inci ilçe) bu ulaşım türünü kullanan ilçeleri gösteren matrisler oluşturulmuştur. Otomobil için ilçeler arası mesafe değeri matrisi, dolmuş için doğrudan ve dolaylı ulaşımın değerlendirilmesi diğer sistemler için iki nokta arasındaki hat sayısı değerlendirilmektedir. Gösterimde kolaylık sağlaması açısından ilçeler küçük harf ile kodlanmıştır (Tablo 6).

$\mathrm{a}=$ Gölbaşı, b=Keçiören, $\mathrm{c}=$ Altındağ $\mathrm{d}=$ Mamak, e=Pursaklar, $\mathrm{f}=$ Yenimahalle, $\mathrm{g}=$ Etimesgut, $\mathrm{h}=$ Sincan, $\mathrm{k}=$ Kahraman Kazan, l=Çubuk, m=Çankaya.

Tablo 6. İlçelerden Geçen Otobüs Hattı Sayısı

\begin{tabular}{|c|c|c|c|c|c|c|c|c|c|c|c|c|}
\hline B (Otobüs) & \multicolumn{12}{|c|}{ Bitiş (Hat Sayısı) } \\
\hline \multirow{12}{*}{ 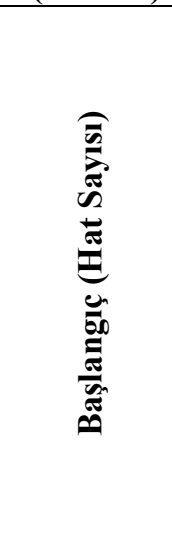 } & İLÇELER & $B_{a}$ & $B_{b}$ & $B_{c}$ & $B_{d}$ & $B_{e}$ & $B_{f}$ & $B_{g}$ & $B_{h}$ & $B_{k}$ & $B_{l}$ & $B_{m}$ \\
\hline & $B_{a}$ & & - & 6 & - & - & 6 & - & - & - & - & 9 \\
\hline & $B_{b}$ & - & & 50 & - & - & 28 & - & - & - & - & 48 \\
\hline & $B_{c}$ & 5 & 3 & & 13 & 1 & 3 & - & - & - & - & 49 \\
\hline & $B_{d}$ & - & - & 41 & & - & 8 & - & - & - & - & 42 \\
\hline & $B_{e}$ & - & 16 & 16 & 1 & 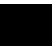 & 4 & - & - & - & - & 10 \\
\hline & $B_{f}$ & 1 & 3 & 2 & 2 & - & & 1 & - & - & - & 5 \\
\hline & $B_{g}$ & - & - & 4 & - & - & 7 & & - & - & - & 17 \\
\hline & $B_{h}$ & - & - & 24 & - & - & 28 & 50 & & - & - & 35 \\
\hline & $B_{k}$ & - & - & 3 & - & - & 6 & 6 & - & & - & 3 \\
\hline & $B_{l}$ & - & 9 & 8 & - & 8 & 4 & - & - & - & & 6 \\
\hline & $B_{m}$ & 1 & 3 & 31 & 7 & 1 & 10 & 13 & 2 & 2 & - & \\
\hline
\end{tabular}

Sonraki adımda, a, b, c, d, e, ..., m’ye kadar sıralanmış ilçelerin sahip olduğu değişkenlerin matrise girilmiş değerleri ilçe bazında ayrı ayrı toplanmaktadır. Ayrı ayrı toplanan değerlerin standardizasyon değerleri şu şekildedir (Tablo 7).

Tablo 7. İlçelere Göre Ulaşım Türlerinin Nicelik Standardizasyon Değerleri

\begin{tabular}{|c|c|c|c|c|c|c|c|c|c|c|c|}
\hline Ulaşım Türü & $\mathbf{a}$ & $\mathbf{b}$ & $\mathbf{c}$ & $\mathbf{d}$ & $\mathbf{e}$ & $\mathbf{f}$ & $\mathbf{g}$ & $\mathbf{h}$ & $\mathbf{k}$ & $\mathbf{~}$ & $\mathbf{m}$ \\
\hline Metro & 0.00 & 0.60 & 1.00 & 0.00 & 0.00 & 0.90 & 0.90 & 0.90 & 0.00 & 0.00 & 0.90 \\
\hline HRS & 0.00 & 0.33 & 0.33 & 0.00 & 0.00 & 0.83 & 0.25 & 0.25 & 0.00 & 0.00 & 1.00 \\
\hline Banliyö & 0.00 & 0.33 & 0.33 & 0.00 & 0.00 & 0.67 & 0.17 & 0.17 & 0.00 & 0.00 & 1.00 \\
\hline Otobüs & 0.10 & 0.54 & 0.88 & 0.39 & 0.19 & 0.40 & 0.33 & 0.47 & 0.07 & 0.12 & 1.00 \\
\hline Dolmuş & 0.80 & 0.87 & 0.87 & 0.67 & 0.73 & 0.80 & 0.80 & 0.87 & 0.67 & 0.73 & 1.00 \\
\hline Otomobil & 0.51 & 0.89 & 1.00 & 0.85 & 0.75 & 0.98 & 0.77 & 0.63 & 0.45 & 0.43 & 0.93 \\
\hline
\end{tabular}

Yerleşimlerin ulaşım nicelikleri bazında elde ettikleri standart değerler başta belirlenen nitelik katsayısı ile çarpılarak elde edilen sonuçlar şu şekilde bulunur (Tablo 8).

Tablo 8. İlçelere Göre Ulaşım Türlerinin Nitelik Standardizasyon Değerleri

\begin{tabular}{|c|c|c|c|c|c|c|c|c|c|c|c|}
\hline Ulaşım Türü & $\mathbf{~}$ & $\mathbf{b}$ & $\mathbf{c}$ & $\mathbf{d}$ & $\mathbf{e}$ & $\mathbf{f}$ & $\mathbf{g}$ & $\mathbf{h}$ & $\mathbf{k}$ & $\mathbf{l}$ & $\mathbf{m}$ \\
\hline Metro $(* 6)$ & 0.00 & 3.60 & 6.00 & 0.00 & 0.00 & 5.40 & 5.40 & 5.40 & 0.00 & 0.00 & 5.40 \\
\hline HRS $(* 6)$ & 0.00 & 2.00 & 2.00 & 0.00 & 0.00 & 5.00 & 1.50 & 1.50 & 0.00 & 0.00 & 6.00 \\
\hline Banliyö $(* 6)$ & 0.00 & 2.00 & 2.00 & 0.00 & 0.00 & 4.00 & 1.00 & 1.00 & 0.00 & 0.00 & 6.00 \\
\hline Otobüs $(* 5)$ & 0.48 & 2.72 & 4.40 & 1.94 & 0.97 & 2.01 & 1.67 & 2.36 & 0.34 & 0.60 & 5.00 \\
\hline Dolmuş $(* 4)$ & 3.20 & 3.47 & 3.47 & 2.67 & 2.93 & 3.20 & 3.20 & 3.47 & 2.67 & 2.93 & 4.00 \\
\hline Otomobil $(* 3)$ & 1.53 & 2.68 & 3.00 & 2.56 & 2.24 & 2.94 & 2.31 & 1.90 & 1.35 & 1.29 & 2.79 \\
\hline
\end{tabular}


Son olarak elde edilen değerler toplandığında metropolitan ilçelerin erişebilirlik düzeyleri Tablo 9'da görüldüğü gibidir;

Tablo 9. Ankara Seçilmiş Metropolitan İlçelerinin Erişebilirlik Düzeyi ve Çeşitli Değişkenler

\begin{tabular}{|c|c|c|c|}
\hline İlçeler & Değer & Nüfus & Ulaşım Türü \\
\hline Çankaya & 29.18667 & 944609 & B, J, L, S, M \\
\hline Yenimahalle & 22.55046 & 687093 & B, J, L, S, M \\
\hline Altındă̆ & 20.87143 & 389510 & B, J, L, S, M \\
\hline Keçiören & 16.46724 & 939161 & B, J, L, S, M \\
\hline Sincan & 15.63061 & 535637 & B, J, L, S, M \\
\hline Etimesgut & 15.08032 & 587052 & B, J, L, S, M \\
\hline Mamak & 7.164626 & 665978 & B, J, S \\
\hline Pursaklar & 6.142007 & 150488 & B, J \\
\hline Gölbaş1 & 5.205459 & 138944 & B, J J \\
\hline Çubuk & 4.821355 & 90764 & B, J \\
\hline Kahramankazan & 4.358096 & 54806 & \\
\hline
\end{tabular}

Erişebilirlik düzeyi haritasında görüldüğü üzere (Şekil 7), Çankaya ilçesi diğer ilçelere kıyasla erişebilirlik düzeyi daha yüksek bir yerleşim olarak karşımıza çıkmaktadır. Bir diğer ifade ile Çankaya ilçesinden herhangi bir noktaya gitmek için birden fazla ulaşım alternatifi bulunmaktadır. Herhangi bir noktadan Çankaya ilçesine gidebilmek, diğer ilçeler göz önünde bulundurulduğunda en fazla sayıda ve en üstün niteliğe sahip ulaşım tür ve seçenekleri ile mümkündür. Otomobil konusunda ise Çankaya ilçesi kentin merkezine yakın olmasından dolayı diğer ilçelere göre yakınlık açısından avantajlı bir konumdadır. Diğer yandan uzaktaki ilçelere erişebilmek için seçeneklerin hem sayısal hem de teknik üstünlük açısından Çankaya ilçesine kıyasla daha zayıf olduğu görülmektedir. Çankaya ilçesi ile herhangi bir sınır bağlantısı olmamasına rağmen Keçiören ilçesinin de erişebilirlik seviyesinin orta üst seviyelerde olduğu görülmektedir. Bu durum, Keçiören ilçesinin son yıllarda ulaşım altyapısının ve toplu taşıma hatlarının artırılması ve metro yatırımı ile güçlendirilmesi ile açıklanabilir. Söz konusu metro hattı, nüfusun yoğun olduğu güzergâh belirlenerek bu bölgeden geçirilmiştir. Mamak ilçesinin Çankaya ilçesine yakın olmasına rağmen erişebilirlik konusunda düşük bir düzeye sahip olması, ilçenin ulaşım yatırımları açısından diğer ilçelere göre daha zayıf bir ulaşım altyapısına sahip olması ile açıklanabilir. Kahramankazan, Çubuk, Gölbaşı gibi ilçeler ise erişebilirlik açısından daha düşük değerlere sahiplerdir. 


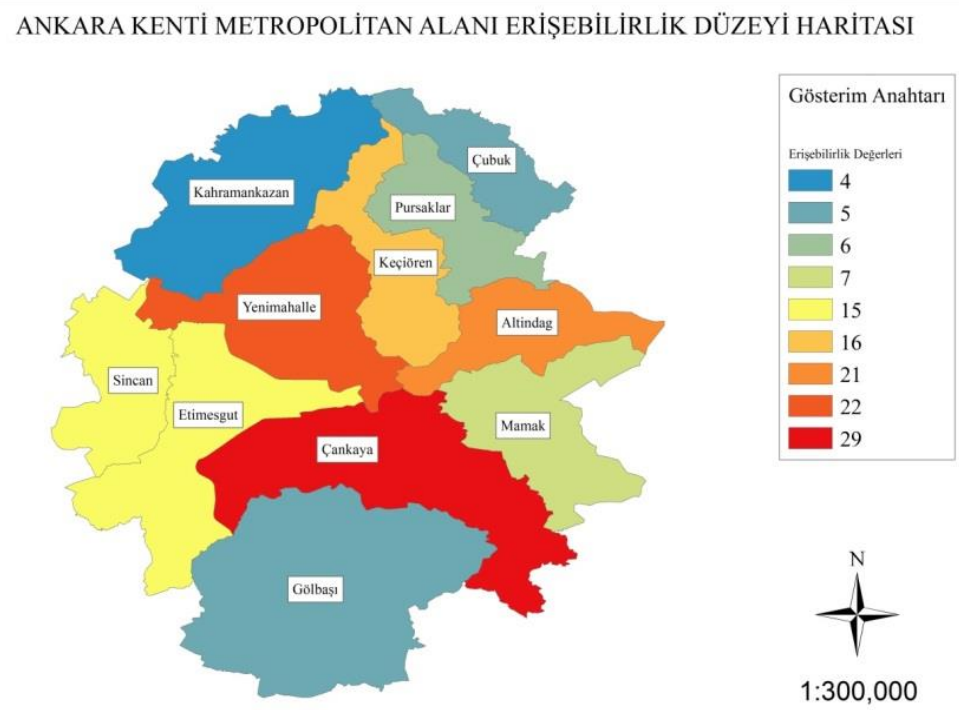

Şekil 7. Ankara Kenti Metropoliten Alan Erişebilirlik Düzeyi

Literatürde birçok çalışma erişebilirlik konusunda tampon sınır (buffer) atılarak oluşturulan mesafe ölçümüne dayalı bir yaklaşım sergilemektedir (Kuntay, Polat ve Lök, 2006; Deniz, Kocaman ve Topuz, 2018; Gülhan ve Yiğit, 2018; Yenice, 2012). Bu çalışmalar yöntem açısından mekânlar arasındaki erişebilirliği tampon sınırların sınırı seviyesinde değerlendirmektedir. Tampon sınır belirlenerek mesafe ölçümü yapmak her ne kadar erişebilirlik konusunda temel bir fikir oluştursa da, ulaşım teknolojileri konusunda yaşanan gelişmeler kişilerin ulaşım alışkanlığı açısından mesafe ölçüm tampon sınırlarının dışına çıkılmasına olanak vermektedir. Çalışma kapsamında üretilen model ile erişebilirlik kavramı mevcut durumu daha detaylı ve gerçekçi olarak ele almaya olanak sağlamaktadır. Geliştirilen model, ölçüm düzeyine göre mekandaki imkanları kümülatif olarak göz önünde bulundurmaktadır. Model, yerleşimlerin içinde yer alan ulaşım türlerini bir kümede ele almaktadır. İnsanların en fazla fayda elde edeceği seçeneği tercih eğilimini göz önünde bulundurmaktadır. Mesafe ve maliyet arttıkça talebin azalacağı negatif fonksiyonu içeren bütüncül bir yapıya sahiptir. Model, mevcut modellerden farklı olarak erişebilirliğin kalitesindeki detaylara, yani nicelik ve nitelik üzerine odaklanmaktadır.

Hesaplanan erişebilirlik düzey değerleri ile TÜIK'ten alınan veriler üzerinden korelasyon analizi yapılmıştır (Tablo 10). Buna göre nüfus ve erişebilirlik düzeyi arasında 0.77 düzeyinde yüksek pozitif bir ilişki var ve erişebilirlik düzeyindeki değişimin \%60'ı nüfus ile açıklanabilir. Bir diğer sonuç olarak ise erişebilirlik düzeyi ile ilçe yüzölçümü büyüklügü arasında -0.44 'lük orta düzey negatif bir ilişki var ve erişebilirlik düzeyinde yaşanan değişimin \%20'si yüzölçümü büyüklüğü ile açıklanabilir.

Tablo 10. Ankara Seçilmiş Metropoliten İlçelerinin Erişebilirlik Düzeyi ve Çeşitli Değişkenler

\begin{tabular}{|c|c|c|}
\hline Değişken & Korelasyonlar & Açıklama Yüzdesi \\
\hline Nüfus & 0,77 & $59 \%$ \\
\hline Yüzölçümü & $-0,44$ & $19 \%$ \\
\hline Çalışan nüfus sayısı (15-64) & 0,77 & $60 \%$ \\
\hline Hane halkı büyüklüğü & $-0,76$ & $57 \%$ \\
\hline Toplam Hane halkı & 0,79 & $63 \%$ \\
\hline Mesken sayıs1 & 0,82 & $67 \%$ \\
\hline İş yeri sayı1sı & 0.94 & $89 \%$ \\
\hline Araç sayısı (2016) & 0.99 & $99 \%$ \\
\hline Otomobil sayısı (2016) & 0.99 & $99 \%$ \\
\hline
\end{tabular}




\subsection{Sosyal Grupların Erişebilirlik Düzeyi}

Bulunan değerlerin bir başka yorumu ise sosyo-demografik grupların erişebilirliği noktasında ele alınabilir. Bu kapsamda Litman, planlama faaliyetlerinin grupların erişilebilirliğine farklı şekilde etki ettiğini vurgulamaktadır (Litman, 2012). Grupların aktivitelerine bağlı olarak gereksinim duyulan ulaşım türleri değişiklik gösterebilmektedir. Örneğin günlük işlerin takibinde birden fazla mekâna rasgele bir zaman diliminde ulaşılması talebi, otomobil odaklı iken daha alt gelir düzeyine sahip insanların ekonomik sürdürülebilirlik perspektifindeki ulaşım talebi toplu taşıma odaklıdır. Odaklar, kişilerin sosyo-ekonomik statülerinden etkilenmektedir. Ayrıca bir diğer belirleyici etmen de güvenlik duygusudur. İnsanlar otomobile, toplu taşımadan daha fazla güvendiği için çocukların ulaşım türü önceliğinde otomobil daha ön plandadır. Litman'ın (2012) farklı gruplar için ulaşım türlerinin önemi üzerine yaptığı araştırmada, ekonomik ve demografik bağımsızlık azaldıkça otomobilin yerini toplu taşımaya bıraktığı görülmektedir (Şekil 8).

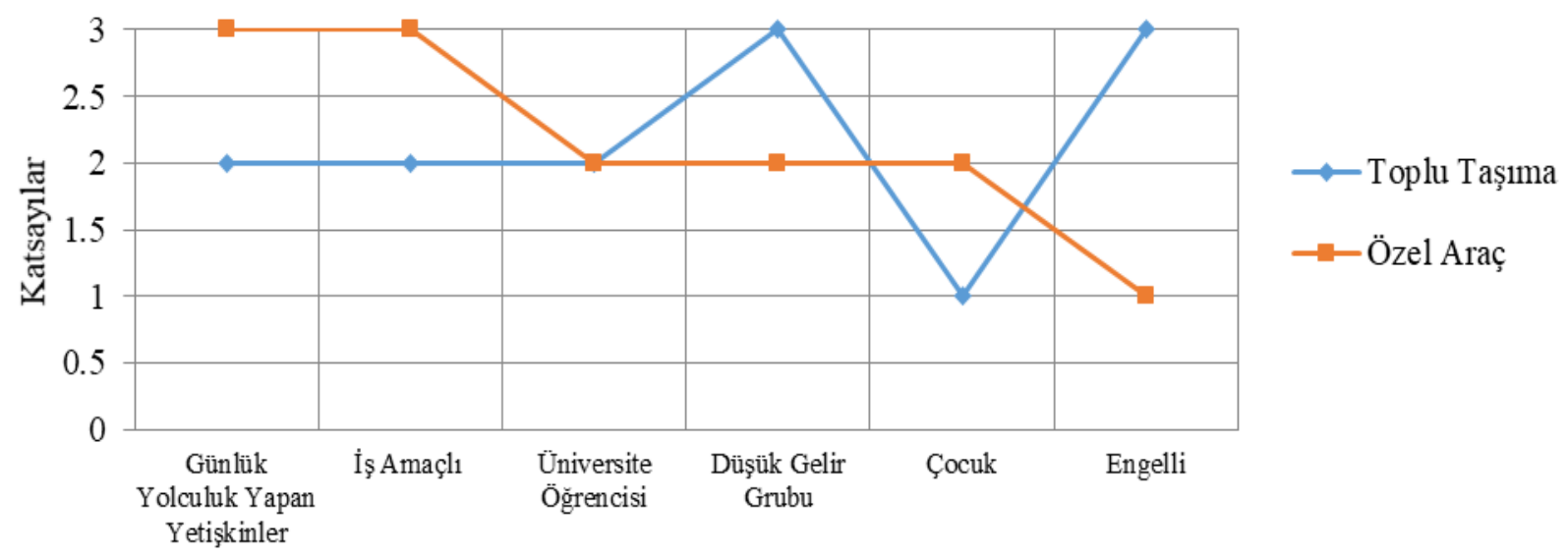

\section{Gruplar}

Şekil 8. Ulaşım Modlarının Önem Katsayıları (Litman, 2012'den yeniden oluşturulmuştur)

Litman'ın çalışmasındaki katsayılar kullanılarak, Ankara'da sosyal grupların erişebilirlik düzeylerine ilişkin erişebilirlik düzeyi hesaplaması yapılmıştır (Tablo 11). Hesaplama yapılırken her ilçenin toplu taşıma toplam değerleri grupların toplu taşıma önem katsayıları ile çarpılmıştır. Otomobil değerleri için de aynı işlem otomobil değerleri kullanılarak yapılııştır. Bu çarpım şu şekilde formüle edilebilir (Formül 3);

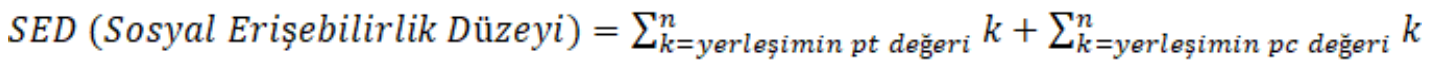

Tablo 11. Sosyal Gruplar Bazında Erişebilirlik Hesabı

\begin{tabular}{|c|c|c|c|c|c|c|}
\hline Gruplar & $\begin{array}{c}\text { Günlük yolculuk } \\
\text { yapan yetişkin }\end{array}$ & $\begin{array}{c}\text { İş amaç̧ı } \\
\text { yolculuk }\end{array}$ & $\begin{array}{c}\text { Üniversite } \\
\text { oğrencisi }\end{array}$ & $\begin{array}{c}\text { Düşük gelir } \\
\text { grubu }\end{array}$ & Çocuk & Engelli \\
\hline TOPLAM & 319.5518361 & 319.5518 & 294.9565529 & 417.83955 & 172.0736 & 393.2443 \\
\hline
\end{tabular}

Görüldüğü üzere Ankara'daki ulaşım çeşitliliği, erişebilirlik açısından en fazla düşük gelirli bireylerin ulaşımına uygun bir yapıya sahiptir. Bir diğer ifadeyle, Ankara kentinin ulaşım sisteminde dar gelirli insanların ihtiyacına cevap verecek, öncelikli önem düzeyine sahip ulaşım altyapıları göreceli olarak diğer gruplarınkinden daha fazladır. Ancak bir diğer sonuç bize göstermektedir ki, Ankara kentinin ulaşım sisteminde çocukların ihtiyaç duyduğu, onlar için önemli olan ulaşım imkânlarının eksikliği söz konusudur. 


\subsection{Otomobil Bağımlılığının İncelenmesi}

Yerleşimlerin taşıt bağımlılığı üzerinden bir başka değerlendirme yapılırsa. Nicelik ve nitelik açısından düşük erişebilirlik düzeyine sahip olan bölgelere ulaşım alternatifi olarak karşımıza otomobil çıkmaktadır. Arazi kullanım açısından çekim düzeyi yüksek olan bölgelerde teknolojik imkânlar dâhilinde ulaşım alternatiflerinin çeşitlendirilmesi, erişebilirlik düzeyini yükseltmektedir. Erişebilirlik düzeyinin yüksek olduğu bölgelerde alternatiflerin çeşitli olması, insanların otomobile olan bağımlılı̆̆ını azaltmaktadır. Otomobil bağımlılığı konusunda yerleşimler, mevcut ulaşım imkânları doğrultusunda otomobile bağımlı, bağımsız ve karma yapılı olarak sınıflandırılabilir. Buradan, yerleşimler arası ulaşım yatırımlarının artması kentleri otomobilden bağımsız ulaşım ihtiyacını karşılayabilecek duruma yaklaştırabilir (Şekil 9).

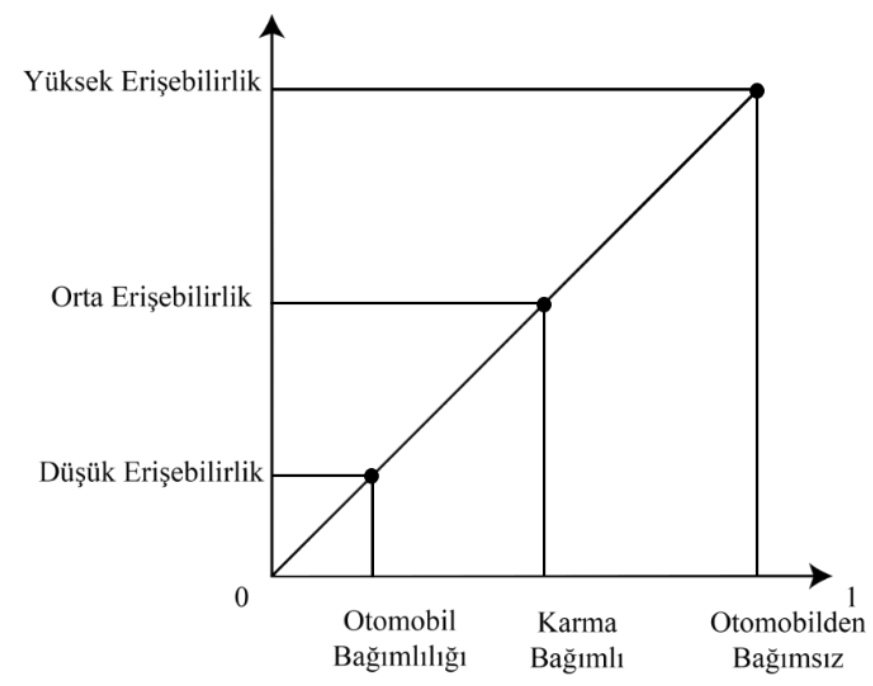

Şekil 9. Erişebilirlik Otomobil Bağımlılığı Diyagramı

Ankara metropoliten alanı ilçelerinin erişebilirlik değerleri, yerleşimlerin sahip olduğu ulaşım türlerinin çeşitliliğini ifade eder. En yüksek erişebilirlik değerine sahip ilçe, türler açısından nitelik ve niceliksel perspektifte en iyi değerlere sahip olan, otomobile en az bağımlı yerleşim olarak yorumlanabilir. En düşük değere sahip ilçe ise otomobil bağımlılığı en yüksek yerleşim olarak yorumlanabilir (Tablo 12).

Tablo 12. İlçelerin Otomobile Duyarlılık Oranları

\begin{tabular}{|c|c|c|}
\hline \multirow{4}{*}{ Otomobil Duyarlılı Oranları } & $15 \%$ & Kahramankazan \\
\cline { 2 - 3 } & $17 \%$ & Çubuk \\
\cline { 2 - 3 } & $18 \%$ & Gölbaşı \\
\cline { 2 - 3 } & $21 \%$ & Pursaklar \\
\cline { 2 - 3 } & $25 \%$ & Mamak \\
\cline { 2 - 3 } & $52 \%$ & Etimesgut \\
\cline { 2 - 3 } & $54 \%$ & Sincan \\
\cline { 2 - 3 } & $56 \%$ & Keçiören \\
\cline { 2 - 3 } & $72 \%$ & Altındağ \\
\cline { 2 - 3 } & $77 \%$ & Yenimahalle \\
\cline { 2 - 3 } & $100 \%$ & Çankaya \\
\hline
\end{tabular}


$\mathrm{Bu}$ durumda ilçelerin sonuçları yorumlandığında Çankaya'nın kent merkezine yakınlığı ve karma kullanımlı kentsel arazi kullanım düzenine sahip olduğu için Çankaya'nın otomobil bağımsız bir yerleşim olma potansiyeli en üst düzeyde, Kahramankazan ilçesinin ise kent merkezine uzak ancak Ankara ile günlük git-gel yolculuklarının, işalışveriş ilişkilerinin fazla olması dolayısıyla otomobil bağımlı bir yerleşim olma potansiyeli en üst düzeydedir.

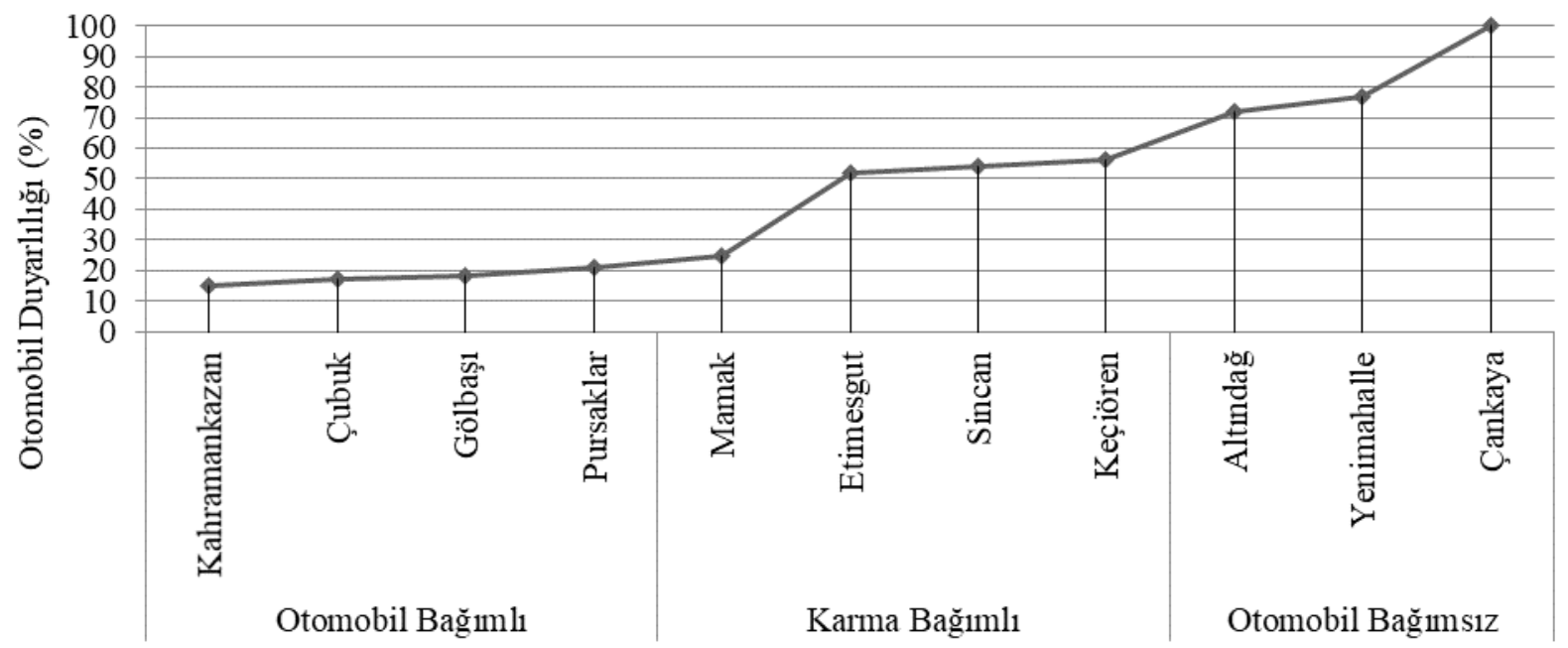

Şekil 10. Ankara Metropoliten Alan Bölgelerine Göre Standardize Otomobil Duyarlılık Diyagramı

Şekil 10'dan yola çıkılarak, Kahramankazan, Çubuk, Gölbaşı, Pursaklar gibi ilçelerinin otomobil bağımlı yerleşimler olduğu; Mamak, Etimesgut, Sincan, Keçiören gibi ilçelerin karma bağımlı olduğu ve Altındağ, Yenimahalle, Çankaya gibi ilçelerin erişilebilirliğinin nicelik ve niteliğinin üst düzeyde olduğu sonucuna ulaşılabilir. Erişilebilirliği yüksek bölgelerde günlük yolculuklar kapsamında otomobil yolculuklarının sayısı az, orta bölgelerde orta seviyede, düşük bölgelerde ise yüksek seviyede olduğu şeklinde yorumlanabilir (Şekil 10).

\section{SONUÇ:}

Ankara metropoliten alanını kapsayan bu çalışma, ulaşımda erişebilirliğin mekânsal etkisini, ilçeler düzeyinde ortaya koymuştur. İlçe düzeyinde yapılan değerlendirmede erişebilirlik kavramı, ulaşım ihtiyacına çözüm üreten kent içi ulaşım araçlarının nitelik ve niceliksel özelliklerini göz önünde bulundurmaktadır. Özellikle vurgulanacak olursa, yapılan bu çalışmada iki mekân arasında daha fazla ulaşım alternatifi olması, aynı ulaşım türüne ait araçtan daha fazla olması gibi durumların, mekânlar arası ulaşım bağlarını yani erişebilirliği kuvvetlendirdiği tespit edilmiştir. Bu düzeyin yükseltilmesinde teknolojik açıdan üstün sistemlerin etkisinin daha fazla olduğu anlaşılmıştır. Dikkat çekici şekilde görülmektedir ki, Keçiören ilçesinde, kent içi ulaşım araçları açısından yaşanan çeşitlilik, erişebilirlik düzeyinin üst seviyelerde olmasında etkili rol oynamaktadır. Ayrıca nüfusu yüksek olan ilçelerin erişebilirlik değerlerinin yüksek olması önemli ve çarpıcı bir sonuçtur.

Özellikle yolculuk talebinin yoğun olduğu Çankaya'nın en yüksek erişebilirlik düzeyine sahip olması, kent merkezine yakınlık özelliğinden dolayı şaşırtıcı olmamaktadır. Bir diğeri ise metropoliten alanın çeperinde yer alan ilçelerin (Kahramankazan, Çubuk, Gölbaşı) erişebilirlik düzeylerinin düşük olmasıdır. Erişebilirlik düzeyi nüfus, çalışan nüfus, toplam hane halkı, mesken sayısı, iş yeri sayısı ile pozitif bir ilişkide iken yüzölçümü ile negatif bir ilişki içerisindedir. Beklenen şekilde kent merkezi ve merkeze yakın ilçelerin otomobil bağımsızlık düzeyleri \%52-\%77 bandında yer alırken, merkezden uzak olan ilçelerin otomobil bağımsızlığı \%15-\%25 gibi düşük seviyelerdedir.

Farklı bir bakış olarak sosyal gruplar açısından erişebilirlik değerlendirildiğinde, Ankara kentsel ulaşım altyapısının en fazla düşük gelir grubundaki insanlara, çocuklardan 2,3 kat daha fazla yönelik olduğu görülmektedir. Dolayısıyla Ankara kentsel ulaşım altyapısının çocukların gerçekleştireceği ulaşım talepleri göz önünde bulundurularak iyileştirilmesi ve geliştirilmesi gerekmektedir. 
Litman'a göre (2017) sosyal açıdan özellikle yüksek erişebilirlik değerlerinin olduğu bölgeler, gençler, yaşlılar, çocuklar, hane halkı ile paylaşımlı taşıt kullananlar ve düşük gelirli gruplara pozitif dışsallık sağlayan kent bölgeleridir. Özellikle düşük gelirli gruplar ve kalabalık hane halkları için erişebilirliğin özellikle bu bölgelerde hem daha hızlı, hem daha ucuz hem de daha etkin şekilde arz-talep dengesini karşılaması gerekmektedir. Planlama açısından yüksek erişebilir bölgelerde sosyo-ekonomik açıdan dezavantajlı gruplara öncelik verilmelidir. Yaşlılar, engelliler, çocuklar ve çocuklu kadınların ulaşım taleplerinin karşılanmasında, erişebilirliğin firsatlarından en üst düzeyde yararlanılması için toplu ulaşımın hizmet saatleri, kalkış sıklığı, ücretleri ve durak-istasyon gibi alanlara erişim kolaylıkları planlar dâhilinde sosyo-ekonomik ve demografik yapı göz önünde bulundurularak düzenlenmelidir. Otomobil bağımlılı̆̆ı, özellikle düşük gelirli kesimler için ulaşım konusunda yapılan harcamalar açısından zorluklar oluşturmaktadır. Bu nedenle gelir düzeyinin düşük olduğu bölgelerde toplu taşıma imkânlarının geliştirilmesi, otomobil bağımlılığının yüksek olduğu bölgelerde ise, otomobil kullanımını kısıtlayıcı ve toplu taşıma kullanımını özendirici önlemler alınmalıdır. Böylece kentin belirli bölgelerinde ve yollarda sıkışıklık ücretlendirmesi, alan ücretlendirmesi, yol giriş ücreti gibi ücretlendirme politikalarının uygulanması ile otomobil kullanımını caydıracak uygulamalar gerçekleştirilebilir. Dahası park et-devam et sistemlerine aktarma için istasyon ve durakların yakınında ücretsiz otoparkların konumlandırılması ile otomobil bağımlılığı azaltılabilir, toplu taşımaya yönlendirme sağlanabilir. Kentin belirli bölgelerindeki trafik sıkışıklığını engellemek ve konut alanlarından kentin merkezi bölgelerine otomobil ile seyahat edilmesini caydıracak otopark politikaları uygulanabilir. Kentin merkezi bölgelerinde otopark ücretlerinin artırıması ve otopark kapasitesinin azaltılması gibi önlemler otomobil bağımlılığını azaltmada faydalı olacaktır. Toplu taşıma ile erişebilirliğin artırılmasının amaçlandığı alanlarda, toplu taşıma taşıtlarında ücretlerin ortalama hane halkı gelir düzeyleri dikkate alınarak yeniden düzenlenmesi, kalkış sıklı̆̆ının artırılması, ilk hareket ve son hareket saatlerinin geniş tutulması, daha kısa ve sürekli güzergâhların oluşturulması, metro, hafif raylı sistem ve banliyö gibi görece daha az esnek ana toplu taşıma güzergâhlarını besleyen ara toplu taşıma hatlarının oluşturulması, toplu taşıma taşıtlarında kalitenin ve konforun artırılması da otomobil kullanımından toplu taşımayı kullanıma doğru geçiş sürecini hızlandıracaktır. Dolayısıyla kentler için emisyon-gürültü-görüntü kirliliği oluşturarak negatif dışsallığa neden olan otomobil bağımlılığının yerini toplu taşımanın kullanımına bırakması ve kentsel ulaşımerişimin toplu taşıma ile sağlanması sosyal ve ekonomik bağlamın yanı sıra çevresel açıdan da birçok fayda sağlayacaktır.

Daha sonra yapılacak ulaşım ve erişebilirlik konulu çalışmalarda bu çalışmadan referansla daha mikro ölçekli değiş̧kenlerin erişebilirliğe etkisi üzerine hassasiyet seviyesi üst düzey bir çalışma yapılabilir. Örneğin farklı ulaşım modlarının kalkış aralığ gibi teknik özelliklerinin erişebilirliğe etkisi incelenebilir. Kentin ulaşım sistemlerinin yolcuların sosyo - ekonomik durumları kapsamında ekonomik esnekliğinin test edilmesi ve karşılanabilirliğin erişebilirlik üzerindeki etkisinin incelenmesi değerlendirilebilir. Bu çalışma kapsamında yapılan değerlendirme ile ileriki aşamada günlük yolcu sayılarının da incelenmesi ile mevsimsel erişebilirlik değerleri ölçülebilir. Ulaşım türlerinin erişebilirlik noktasında birbirine göre nicel ve nitel üstünlüklerinin sayısal değerlerinin tespiti hususunda çalışmalar gerçekleştirilebilir. Bu çalışma erişebilirlik ile ilgili standartlara yönelik daha detaylı sonuçların elde edilmesi amacıyla bulanık mantık kullanılarak yapılabilir. Ayrıca küçük orta ve büyük şehirlerin erişebilirlik düzeylerinin karşılaştırılması yapılarak, şehirler bazında daha çok ilçenin kıyaslanabilmesi ve veri setinin güncellenmesi ile yıllara göre erişebilirlik düzeylerindeki değişim ortaya koyulabilir.

\section{Etik Standart ile Uyumluluk}

Çıkar Çatışması: Yazarlar herhangi bir çıkar çatışmasının olmadığını beyan eder.

Etik Kurul İzni: Bu çalışma için etik kurul iznine gerek yoktur.

\section{KAYNAKÇA:}

Allen, J., Farber, S. (2020). A Measure of Competitive Access to Destinations for Comparing Across Multiple Study Regions. Geographical Analysis, 52(1), 69-86.

Campbell, K. B., Rising, J. A., Klopp, J. M., ve Mbilo, J. M. (2019). Accessibility Across Transport Modes and Residential Developments in Nairobi. Journal of Transport Geography, 74, 77-90. 
Cervero, R. (2013). Linking Urban Transport and Land Use in Developing Countries. Journal of Transport and Land Use, 6(1), 724.

Dell'Olio, L., Ibeas, A., ve Cecin, P. (2011). The Quality of Service Desired by Public Transport Users. Transport Policy, 18(1), 217-227.

Erdoğan, H. (2016). Ulaşım Hizmetlerinin Ekonomik Kalkınma Üzerine Etkisi. İstanbul Gelişim Üniversitesi Sosyal Bilimler Dergisi, 3 (1), 187-215. DOI: 10.17336/igusbd.05060

Geurs, K. T., ve Van Wee, B. (2004). Accessibility Evaluation of Land-Use and Transport Strategies: Review and Research Directions. Journal of Transport Geography, 12(2), 127-140.

Gökalp, S. (2019). Türkiye'de Yerel Yönetimler ve Toplu Taşımacılık Sistemlerine Genel Bir Bakış: Ankara Büyükşehir Belediyesi Örneği. Kent Akademisi, 12 (1), 135-147

Gülhan, G. Yiğit, H. İ. (2018) Taksi Duraklarının Konum ve Kapasitelerinin, Erişilebilirlik Ölçütleri ve Nüfus Dağılımı Kapsamında Değerlendirilmesi: Tekirdağ-Çorlu Örneği. Iğdır Üniversitesi Fen Bilimleri Enstitüsü Dergisi, 8(3), $153-166$.

Gündoğdu, M., Uğuz, B., (2020). İnsan-Mekân Etkileşimi Bağlamında Kırklareli Merkez Yayla ve Vilayet Meydanları Kullanılabilirlik Durumunun Araştırılmas1, Kent Akademisi, 13, 2, 315-337.

Hallgrimsdottir, B., Wennberg, H., Svensson, H., ve Ståhl, A. (2016). Implementation of Accessibility Policy in Municipal Transport Planning-Progression and Regression in Sweden Between 2004 and 2014. Transport Policy, 49, 196-205.

Hansen, W. G. (1959). How Accessibility Shapes Land Use. Journal of the American Institute of Planners, 25(2), 73-76.

Kuntay, O., Polat, S. ve Lök, S. (2006). Erişilebilirlik, Planlama, 2006.

McCahill, C., Jain, S., ve Brenneis, M. (2020). Comparative Assessment of Accessibility Metrics Across the US. Transportation Research Part D: Transport and Environment, 83, 102328.

Mokhtar, H. M. (2011). HITS: A History-Based Intelligent Transportation System. International Journal of Data Mining ve Knowledge Management Process, 1, 34-46.

Pan, G., Qi, G., Wu, Z., Zhang, D., ve Li, S. (2012). Land-Use Classification Using Taxi GPS Traces. IEEE Transactions on Intelligent Transportation Systems, 14(1), 113-123.

Quiros, T.P., Mehndiratta, S.R., 2015. Accessibility Analysis of Growth Patterns in Buenos Aires, Argentina: Density, Employment, and Spatial Form. Transport Research Record, 25,12, 101-109. https://doi.org/10.3141/2512-12.

Stjernborg, V., Emilsson, U. M., ve Ståhl, A. (2014). Changes in Outdoor Mobility When Becoming Alone in the Household in Old Age. Journal of Transport ve Health, 1(1), 9-16.

Şïmşek, G. ve Yeşiltepe, A. (2020). Eskişehir Kenti Porsuk Çayı Kıyısında Mekânsal Örüntü ve Suyla Kurulan Bağlantının Analizi. Kent Akademisi, 13 (3) , 487-512.

Tiznado-Aitken, I., Muñoz, J. C., ve Hurtubia, R. (2021). Public transport accessibility accounting for level of service and competition for urban opportunities: An equity analysis for education in Santiago de Chile. Journal of Transport Geography, 90, 102919.

Yenice, M. (2012). Kentsel Yeşil Alanlar İçin Mekansal Yeterlilik ve Erişebilirlik Analizi; Burdur Örneği, Türkiye. Turkish Journal of Forestry, 13(1),41-47. Dergipark web sitesinden 9 Mayı 2020 tarihinde erişildi: https://dergipark.org.tr/tr/pub/tjf/issue/20898/224396

\section{Bildiriler}

Deniz, M., Kocaman, E., ve Topuz, M. (2018). Turgutlu İlçesinde Aile Sağlığı Merkezlerinin (ASM) Konumlarının Erişilebilirlik Açısından CBS ile Analizi-TÜCAUM 30. Y1l Uluslararası Coğrafya Sempozyumu Bildiriler Kitabı, 704-712. 
Stenneth, L., Wolfson, O., Yu, P. S., ve Xu, B. (2011). Transportation Mode Detection Using Mobile Phones and GIS Information in Proceedings of the 19th ACM SIGSPATIAL International Conference on Advances in Geographic Information Systems (pp. 54$63)$.

\section{Kitaplar}

Elker, C. (2012). Kentsel Ulaşım: Ulaşım Sistemi-Toplu Taşım-Planlama-Politikalar, T. Kılınçaslan (Ed.). ss. 235-250. İstanbul: Ninova Yayınları.

Gourdin, K. (2006). Global Logistics Management: a Competitive Advantage for the 21st Century. Wiley-Blackwell.

Kırmızı, Z.Z., Kolağasığlu, M. Ş., ve Çalışkan, F. T. (2012). Kent İçi Ulaşım Terimleri Sözlüğü: Dictionary of Urban Transport Terms. İstanbul: Cinius Yayınları.

Keleş, R. (1998). Kentbilim Terimleri Sözlüğ̈̈. Ankara: İmge Kitabevi.

Levine, J., Grengs, J. ve Merlin, L.A., (2019). From Mobility to Accessibility: Transforming Urban Transportation and Land-Use Planning. Cornell University Press, Ithaca, NY.

Şenbil, M. (2012). Erişebilirlik. Kentsel Planlama Ansiklopedik Sözlük. Melih Ersoy (Ed.). Ninova Yayınları. 2012. pp 118.

\section{Resmi Kaynaklar}

Avner, P. ve Lal, S.V., (2016). Matchmaking in Nairobi: the Role of Land Use. In: World Bank Policy Research Working Paper.

Habitat, U. N. (2016). World Cities Report 2016: Urbanization and Development: Emerging Futures. Nairobi: UN Habitat.

UNDP (2016). Sürdürülebilir Kalkınma için Küresel Amaçlar: Amaç 11. Sürdürülebilir Şehirler ve Topluluklar, UNDP Türkiye web sitesinden 15 Mayıs 2020 tarihinde erişildi: https://www.tr.undp.org/content/turkey/tr/home/sustainable-developmentgoals/goal-11-sustainable-cities-and-communities.html

\section{Web Kaynakları}

Kahn Ribeiro, S., Figueroa, M. J., Creutzig, F., Dubeux, C., Hupe, J., ve Kobayashi, S. (2012). Energy End-Use: Transport, International Instute for Applied Systems Analysis web sitesinden 21 Nisan 2020 tarihinde erişildi: https://iiasa.ac.at/web/home/research/Flagship-Projects/Global-Energy-Assessment/GEA Chapter9 transport lowres.pdf.

Litman, T. (2012). Evaluating Accessibility for Transport Planning. Measuring People's Ability to Reach Desired Goods and Activities. Victoria Transport Policy Institute web sitesinden 21 Nisan 2020 tarihinde erişildi: https://www.vtpi.org/access.pdf, pp.28.

Litman, T. (2017). Evaluating Transportation Diversity. Victoria Transport Policy Institute web sitesinden 21 Nisan 2020 tarihinde erişildi: https://www.vtpi.org/equity.pdf, pp.24

Litman, T. (2018). Evaluating Transportation Diversity. Multimodal Planning for Efficient and Equitable Communities, Victoria Transport Policy Institute web sitesinden 21 Nisan 2020 tarihinde erişildi: http://www.vtpi.org/choice.pdf, pp.8.

Litman, T. (2020). Introduction to Multi-Modal Transportation Planning. Principles and Practices, Victoria Transport Policy Institute web sitesinden 21 Nisan 2020 tarihinde erişildi: https://www.vtpi.org/multimodal_planning.pdf

Litman, T. (2020). Evaluating Accessibility for Transport Planning: Measuring People's Ability to Reach Desired Goods and Activities, Victoria Transport Policy Institute web sitesinden 21 Nisan 2020 tarihinde erişildi: https://www.vtpi.org/access.pdf.

Yüksek Kapasiteli Ulaşım Türlerinin Kıyaslanması, Planitmetro web sitesinden 15 Mayıs 2020 tarihinde erişildi: https://planitmetro.com/2014/05/14/how-do-different-modes-compare/ 